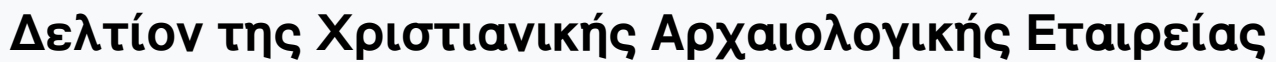

Tó 12 (1986)

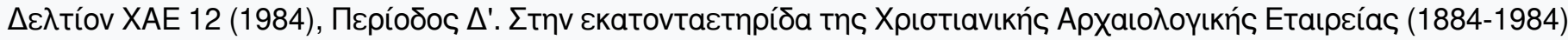

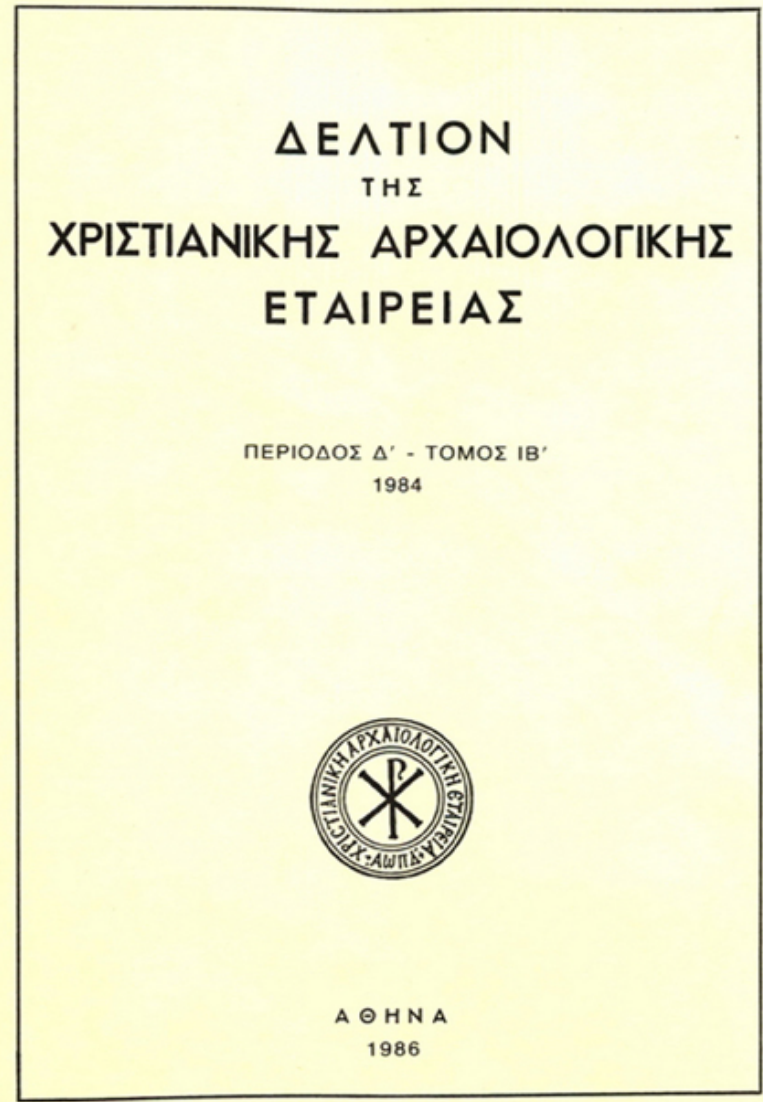

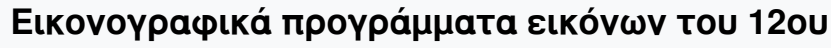

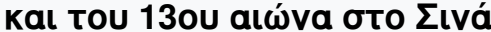

Kurt WEITZMANN

doi: $\underline{10.12681 / \text { dchae.947 }}$

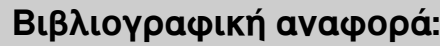

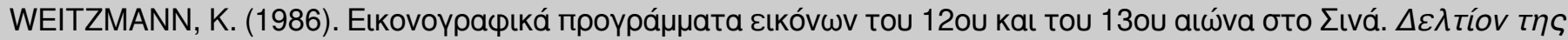

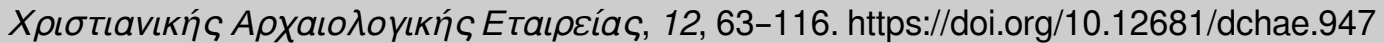




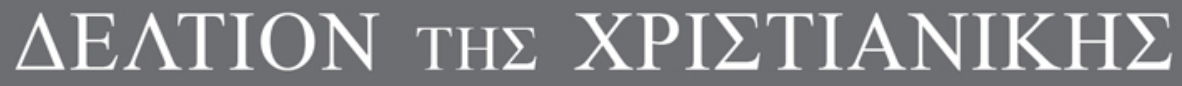 APXAIO $\Lambda$ OГIKH $\Sigma$ ETAIPEIA $\Sigma$}

Icons Programs of the 12th and 13th Centuries at Sinai

Kurt WEITZMANN

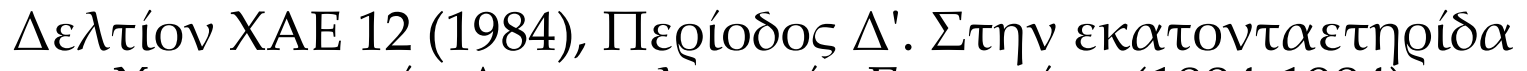

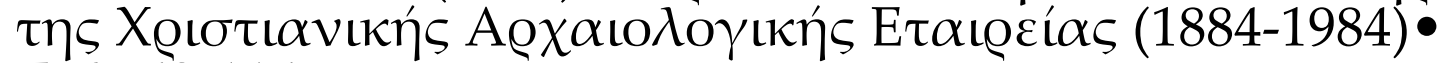
$\sum \varepsilon \lambda .63-116$

A@HNA 1986 


\section{ICON PROGRAMS \\ OF THE 12th AND 13th CENTURIES AT SINAI}

It seemed proper to write for the volume which celebrates the 100th anniversary of the Christian Archaeological Society of Athens on the subject of Sinai icons, a subject on which I had the pleasure to write in the Festschrift honoring George Sotiriou published in the same journal almost 20 years ago ${ }^{1}$. George Sotiriou and his wife Maria were the first to call attention to what turned out to be the greatest and most important icon collection in any Greek monastery which has almost miraculously survived, and their publication of a selection of $c .150$ of the most important icons forms the foundation of any future research on this subject ${ }^{2}$. Their work has been continued by the writer of these lines with the idea to publish a corpus of the collection which possesses more than ten times as many icons than were published by the Sotirious, although it must clearly be stated that a major part are either too late, or too damaged or artistically insignificant to be included in any publication. So far only the first volume of the corpus has appeared which contains the icons from the 6 th-10th century ${ }^{3}$, and a second volume on the 11th-12th century icons is in progress. But realizing that it surpasses the capacity of a single person to publish such a corpus, I have proposed to Manolis Chatzidakis, the great expert especially on Cretan icons, to write the volumes on those of the post-Byzantine period and I am glad that he has accepted this proposition and that we can expect, before long I hope, to see the publication of his first volume. It will be published by the Academy of Athens as part of the corpus of the monuments of Sinai, laid out by the Sinai Expedition undertaken by the Universities of Alexandria, Michigan and Princeton. As the result of this cooperation at least a part of the American Sinai project will be worked out in Athens by an Athenian scholar.

The following lines, which will deal only with one particular aspect of the Sinai icon collection, should be considered merely as a sketch and should be understood as only one of several prolegomena to the future volumes of the corpus. The primary concern of the present study is neither a detailed analysis of style nor of iconography, but of the function of the icon and of its original placing in the church though this can be determined, as we shall see, with certainty in only a limited number of cases.

1. K. Weitzmann, Fragments of an Early St. Nicholas Triptych on Mount Sinai, $\triangle \mathrm{XAE}, \Delta^{\prime}$, $\Delta^{\prime}(1964-65)$, pp. $1 \mathrm{ff}$.

2. Sotiriou, Icônes, I-II, 1956 and 1958.

3. Weitzmann, Sinai Icons, I. 
We shall try to produce the evidence that the 12th and 13th centuries were the period of the greatest accumulation of icons in the long history of Sinai and that in this period coherent programs were worked out for the decoration of the church and the various chapels. When one walks today through the various places in the monastery where icons are to be found it will become immediately clear that hardly any are still in the place for which they were destined. It is true that the impressive main iconostasis of the basilica is made according to a unified plan and filled with icons by the Cretan painter Jeremias in 1612, but by far the majority of chapels within the church and within and outside the monastery possess makeshift iconostases of a late period and are filled at random with icons of various periods, often with pieces of wood added where the provided space was too big or sawed off where it was too small. Moreover, on the upper walls of the basilica are icons of large format too high up to be still accessible to worship and to burn candles in front of them. Furthermore, during my early visits the walls of the side chapels of the basilica were filled several rows above each other like an icon magazine, but then, for security reasons, transferred into the double room of the former library which was turned into a magazine of icons. When I first visited Sinai in 1956 I made a checklist and counted more than 600 icons on the former bookshelves. As the result of subsequent transfers this magazine now contains more than 1,000 . Moreover, when the new concrete building was erected, partly for the greater safety of the library, a special room was reserved for a selection of the most valuable icons, a selection which, if I am correctly informed, was made by the Sotirious. It is worthwhile noticing that at the entrance door there is a label, "Picture Gallery". This clearly reflects an attitude of modern times in which the icons, having been deprived of their original function as objects of worship, have become uprooted museum objects.

But when in the 17th century and thereafter new iconostases were carved, they were filled at random with older icons mostly from earlier periods, replacing older iconostases. The clearest evidence for such substitution is the existence of a great number of iconostasis beams which, with two exceptions, no longer serve their original purpose and even they are not in the places for which they were destined. Yet the beams are our primary evidence of what the focal point of a chapel decoration must have looked like at the time when they were still in place.

\section{A. THE ICONOSTASIS BEAMS}

The Sotirious clearly recognized the significance of the beams, of which an unusually great number are preserved at Sinai, while otherwise only a few 
fragments exist ${ }^{4}$. But while they gave them a very prominent place in their book $^{5}$, they published only about half of them. Because of their great importance for icon painting at Sinai in general, I am going to present here the full evidence of them, making only a few additional remarks to those dealt with already by the Sotirious and dealing in somewhat greater detail with the material not included in their publication. What makes the beams so important is the fact that they must have been produced ad hoc in the monastery where they were made in accordance with the width of the respective chapel in which they were placed. In some cases, as we shall see, icons in the same or closely related style exist at Sinai, a fact from which we conclude that the painter or painters engaged in the production of a beam were not called to the monastery for the beams alone, and thus we must assume, at least in some cases, the establishment of larger workshops.

The Sotirious started the series of beams with two planks, each of which contains three scenes comprising together the second half of the dodecaorton, i.e. Entry into Jerusalem, Crucifixion, Anastasis, Ascension, Pentecost and Koimesis ${ }^{6}$. They no longer serve as an iconostasis beam, but decorate the walls of a side chapel of the basilica dedicated to Constantine and Helen ${ }^{7}$. Apparently the Sotirious did not take them to be part of the same beam because they dated them slightly differently, the first plank into the first half of the 11th century (surely just a printing error and meant to be 12th century) and the second into the 12 th century in general. They may have been misled by the fact that the second plank is of lesser height, but this is surely due to the fact that the lower frame was sawn off. Both parts show an identical style and are placed under the very same type of an arcade filled with a geometrical pattern which betrays its derivation from cloisonné enamels. It may be recalled that the upper part of the Pala d'Oro in San Marco in Venice actually is a part of what was originally an enameled iconostasis beam ${ }^{8}$.

4. See esp. V. Lasareff, Trois fragments d'épistyles peintes et le templon byzantin and $\mathrm{M}$.

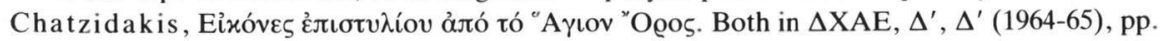
$117 \mathrm{ff}$. and pp. $377 \mathrm{ff}$.

For the most basic and complete treatment of the decoration of the beam within the general history of the iconostasis see M. Chatzidakis, Ikonostas in Rbk, 1978, col. $326 \mathrm{ff}$.

5. Sotiriou, Icônes, I, figs. 87-125; II, pp. $100 \mathrm{ff}$.

6. Ibid., I, figs. 87-94; II, pp. 102 ff. Weitzmann, A Group, pp. 54 f. and pl. 27a-b (Anastasis). Weitzmann, Byzantium and the West, p. 55 and fig. 6 (Pentecost). Weitzmann, St. Peter Icon, p. 26 and fig. 27 (Pentecost).

7. The plank with the Entry, Crucifixion and Anastasis measures $44.3 \times 118 \mathrm{~cm}$., the one with the Ascension, Pentecost and Koimesis $38.7 \times 118.7 \mathrm{~cm}$.

8. Weitzmann, Crusader Icons, p. 163 and fig. 28 (here further bibliography). 


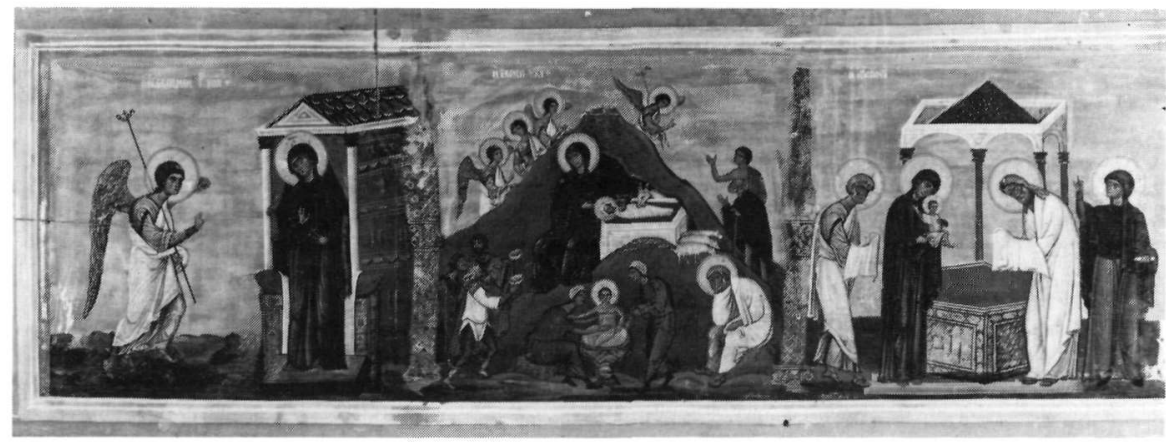

Fig. 1. Chapel of St. George. Beam with Annunciation, Nativity and Presentation in the Temple.

In the Chapel of St. George on top of a tower of the north wall of the monastery I noticed two planks used for the decoration of an iconostasis for which they surely were not destined. They no doubt form the first half of the same beam we just discussed, representing on the first plank (Fig. 1) ${ }^{9}$ the Annunciation, the Birth of Christ and the Presentation in the Temple, and on the other (Fig. 2) ${ }^{10}$ the Baptism, the Metamorphosis and the Raising of Lazarus. They are insensitively placed in the wrong sequence, i.e. starting at the left with the Baptism instead of the Annunciation. The rest of the epistyle is filled at the left with a 12th century icon with the bust of St. Peter ${ }^{11}$ and at the right with an icon with a bust of St. George of the post-Byzantine period. This means that there would have been no place for the two planks now in the side chapel of the basilica and that the complete beam consisting of the four planks must originally have been in a chapel of larger dimensions. The first plank with the Annunciation, Nativity and Presentation in the Temple is covered by a dark varnish and, besides, has been heavily overpainted, probably in the 18th century when the gold ground was overpainted in light blue in a taste characteristic of that period by the ubiquitous painter Ioannes Cornaros. A partial cleaning between the scenes revealed the arcade with the same enamel pattern as the other three planks. On the other hand the second plank with the Baptism, the Metamorphosis and the Raising of Lazarus has been overcleaned. The four planks form, thus, a complete and one of the earliest renderings of the dodecaorton in what one might call its canonical form. As we shall see later, other beams have in the very center of the beam a

9. Unpublished. It measures $43.8 \times 118.3 \mathrm{~cm}$.

10. The Baptism is unpublished. Weitzmann et al., Frühe Ikonen, p. XIV and figs. on pp. 25-29 (Lazarus and Metamorphosis). Weitzmann, A Group, p. 51 and pl. 19a (Lazarus).

11. Weitzmann, St. Peter Icon, p. 7 and fig. 4 . It measures $43.8 \times 33.2 \mathrm{~cm}$. 


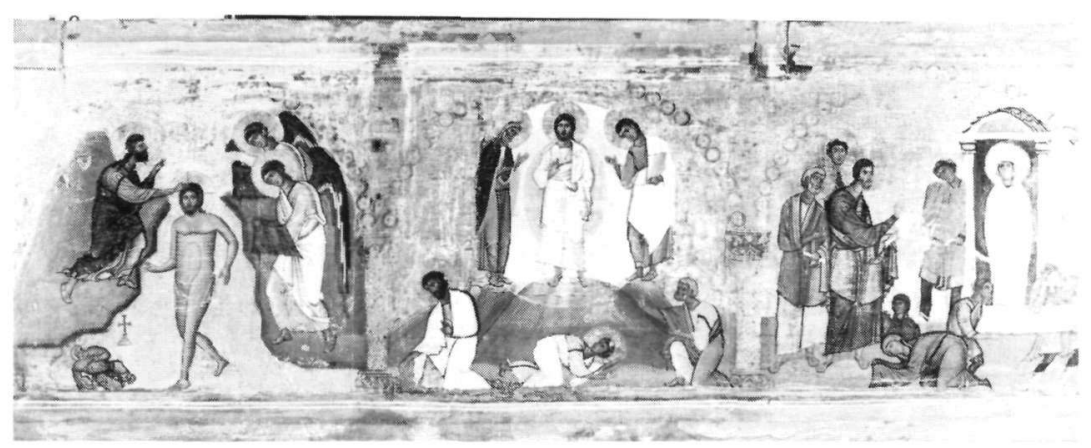

Fig. 2. Chapel of St. George. Beam with Baptism, Metamorphosis and the Raising of Lazarus.

representation of the Deesis, but it is not likely that our beam had one which might be lost. In all other cases the Deesis is part of a plank on which it is flanked by other scenes and it never seems to have been on a single panel.

We have elsewhere discussed the style of this beam and attributed it to a Cypriote painter from the early 12 th century and grouped around it a few icons in the Sinai collection of which the most outstanding is one representing Abraham and Melchisedek ${ }^{12}$. Thus we assume that a Cypriote workshop was established at Sinai and was active more or less during the first half of the 12th century and that its head was the artist we call "the Abraham and Melchisedek master".

There may have existed organized workshops at Sinai before the 12th century, a problem which still needs to be investigated. But, if this was the case they did not leave behind such a large and well-defined œuvre like that of the "Abraham and Melchisedek master". In addition to a number of single icons, we attribute another major work to this master, a second iconostasis beam. It is an unusual beam in that it does not depict the dodecaorton, but some miracles of the five martyrs of Sebaste ${ }^{13}$. At the present exhibited in the bacilica in the Chapel of Constantine and Helen it once must have decorated the iconostasis in the chapel dedicated to the five martyrs, a chapel which still exists within the walls of the monastery. There are only two insignificant post-Byzantine icons left today in this chapel and the beam was, apparently for reasons of safety, brought in modern times into the basilica. It is only because

12. Weitzmann, A Group, p. 54 and pls. 21 and 22c.

13. Sotiriou, Icônes, I, figs. 103-111; II, pp. 109 ff. Weitzmann, A Group, pp. 52 ff. and pls. 20a-b. Weitzmann, The Icon, pl. 19 (color). K. Weitzmann, Illustrations to the Lives of the Five Martyrs of Sebaste, DOP 33 (1979), pp. 108 ff. and figs. 28-39. Weitzmann, Ikonen, pl. .8 (color). 


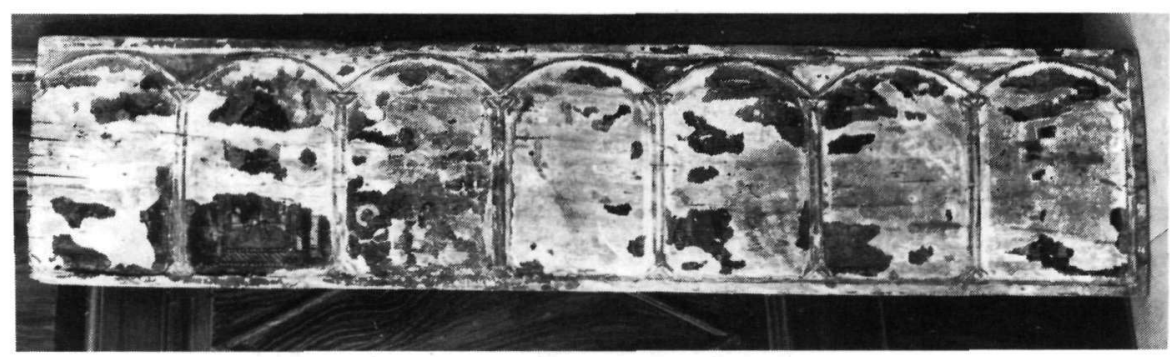

Fig. 3. Old Library Beam with New Testament and Life of St. Nicholas.

of its distinct iconography that in this case the original location of the beam can still be determined.

It seems rather odd that the Deesis is not in the center of the beam, but because the width of the iconostasis apparently permitted only an even number of arches, it had to be placed off center, so that five scenes of the narrative cycle were placed to the left and six to the right. The drapery of the figures is somewhat more simplified than that of the figures in the dodecaorton beam. But this slight difference we are inclined to attribute not to different hands, but to different models: the miracle scenes owe their greater simplicity to the model which we presume was an illustrated manuscript. In such a model the figures were smaller and this would account for the simplification as the result of their enlargement.

Presumably it was at all times a rare case to have the life of a saint used as the theme of an iconostasis beam but the one with the five martyrs of Sebaste is not the only one at Sinai. There is a fragment of a beam in the Old Library with a mixed program containing some scenes of the dodecaorton and others from the life of St. Nicholas (Fig. 3) ${ }^{14}$. It is in an extremely bad condition and most of the surface has flaked off, but fortunately enough traces of the inscriptions are preserved which help to identify each scene under the seven sculptured arches. The second scene from the left is the only case in this beam where a little more than half of the surface is preserved. It represents the Deesis with an enthroned Christ flanked by the Virgin and, very exceptionally, not by John the Baptist but by a bishop. Chatzidakis identified him as John Chrysostom. I have not been able to detect any remnant of an inscription to verify this identification, but in the context of the beam we should like to identify him as St. Nicholas. At the left and the right of the Deesis are the Annunciation and Nativity of Christ, i.e. the first two scenes of the dodecaorton. Then follow to

14. Chatzidakis, L'évolution, p. 171 and pl. XXXIII, 14. N. Ševčenko, The Life of Saint Nicholas in Byzantine Art, Turin 1983, p. 31 no. 5 and figs. 52-53. 
the right three scenes from the life of St. Nicholas, of which the first is almost

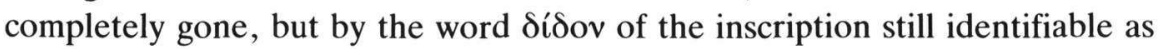
the scene in which Nicholas gives money to the three impoverished maidens. Next is the scene in which St. Nicholas saves three men from execution, and the third shows the death of St. Nicholas. In the final arch stand the two soldier saints inscribed St. Demetrios and St. George. There can be no doubt that the Deesis once formed the center of the beam and that consequently, following a symmetrical arrangement, a plank with four more scenes is missing. To the left of the Annunciation there must have been three more scenes from the life of St. Nicholas which can be determined with more than a high degree of probability. In the normal cycle the story with the three maidens is preceded by the birth of Nicholas, his education and his consecration first as Deacon, then as Priest and finally as Bishop. So the missing scenes we propose to have illustrated are Nicholas' birth, his education and one of the three consecrations, most likely that as a bishop. Apparently the painter had used an established cycle of normally 16 scenes, copied the first four in the original sequence and then, having only space for two more, epitomized in the last two scenes. Though the damaged state of preservation permits no definite conclusions, the possibility exists that the painter working at Sinai used an 11th century triptych as model which existed in the monastery's collection ${ }^{15}$. Three of the scenes of the beam, the presumed ordination, St. Nicholas saving the three men and his death occur on the preserved right wing of the triptych and the other three could well have been on the lost left wing.

To have saints, especially soldier saints, at the ends of a beam is not without parallels. There is the fragment of a beam from the 11th-12th centuries in the Hermitage in Leningrad ${ }^{16}$ which had originally the twelve apostles of whom, however, only one, Philip, is at the left and next to him are St. Theodore and St. Demetrios. No doubt the other end of the beam had correspondignly St. George and most likely St. Procopios. Correspondingly the left end of our Nicholas beam should have had St. Theodore and St. Procopios.

To judge from the few remnants of paint, particularly from the way the gold striation is applied in a sprightly manner, we propose a date around 1200 . We know that in that part of the monastery where now the new wing in concrete

15. Weitzmann, op. cit. (note 1), pp. 1 ff. and figs. 1-3. Weitzmann et al., Frühe Ikonen, p. XIII and p. 17 (color). Weitzmann, Eleventh Century, p. 213 and pl. 18a-b. Ševčenko,op. cit., p. 29 no. 1 and p. 178 with four figures.

16. Lasareff, op. cit. (note 4), p. 117 and fig. 1. A. B ank, Byzantine Art in the Collections of the Soviet Union, Leningrad 1977, pls. 239-241 (color). Weitzmann, Crusader Icons, p. 158 and fig. 21. 
was built, there existed a chapel dedicated to St. Nicholas and there can be little doubt that our beam was made for that chapel.

Coming back after this interlude of a beam with a saint's life to the beams devoted in their program entirely to the dodecaorton, of the next to be discussed, two planks are preserved which the Sotirious had treated separately, one of them being kept in the Old Library, the other in a side chapel of the basilica ${ }^{17}$. One is the central of three planks depicting the Deesis in the center, to the left of it the Baptism and the Metamorphosis, and to the right the Raising of Lazarus and the Entry into Jerusalem. The other plank has the first three scenes of the dodecaorton, Annunciation, Nativity of Christ and the Presentation in the Temple preceded by two scenes from the Life of the Virgin, her Birth and her Presentation in the Temple. What the Sotirious had not realized is that both, judging from their style and measurements ${ }^{18}$, are parts of the same beam ${ }^{19}$. Missing is the third plank which surely contained the last five feasts, i.e. Crucifixion, Anastasis, Ascension, Pentecost and Koimesis. What is unusual in this beam is the addition of the two Virgin feasts at the beginning of the cycle. As the result of this addition the Deesis is not as usual in the center of the dodecaorton, i.e. between the Raising of Lazarus and the Entry into Jerusalem where it divides Youth and Miracles of Christ on the one side from the Passion on the other, but between Metamorphosis and Raising of Lazarus whereby the equilibrium between Youth and Passion of Christ is somewhat disturbed. The Sotirious treating, as said above, the two planks separately, connected the first stylistically mainly with the mosaics of Monreale and the second with the frescoes of Nerezi from 1164 A.D. They, I believe, dated them correctly in the mature Comnenian period and attributed them also correctly, I believe, to a Constantinopolitan workshop. Actually the connection with Nerezi is even closer than that with the Sicilian mosaics and the emphasis on emotional expression in the faces for which Nerezi is the first firmly dated monument suggests that also the two beam parts belong to the third quarter of the 12th century.

Assuming that all the beams were made ad hoc in the monastery, the question arises whether the artist, who most likely had come from Constantinople or was at least thoroughly trained in the style of the capital, produced

17. Sotiriou, Icônes, I, figs. 95-102; II, pp. 105 ff. Weitzmann, Byzantium and the West, pp. 24 passim and figs. 14, 17, 20, 22, 24, 30. Weitzmann, The Icon, fig. VII an pl. 24 (color, Metamorphosis). Huber, Heilige Berge, p. 152 and figs. 120-121 (color, Annunciation and Nativity). Weitzmann et al., The Icon, pl. on p. 58 (color, Lazarus).

18. Plank with Birth of Virgin - Presentation of Christ in the Temple measures $40.8 \times 141.5 \mathrm{~cm}$. The plank with Baptism - Entry into Jerusalem measures $41.5 \times 159 \mathrm{~cm}$.

19. The slight difference in height can easily be explained by the fact that the second plank had been slightly sawed off at the bottom. 
other icons during his stay at Sinai. At the present state of our knowledge, one cannot be certain about it, but only suggest that there is a good chance that this is the case, because there are several first-rate icons in the style of the capital which are more or less contemporary and are closely related to the beam cycle. The icon with the Archangel at Chonai, e.g. ${ }^{20}$, surely a Constantinopolitan product of this period shows the archangel draped in a mantle which brings out a high degree of plasticity over the thigh bordered by a cascade of long straight folds, features which occur quite similarly in the Christ figure of the Metamorphosis in the beam. But as in all such parallel cases discussed in this paper, we can offer only a lead which will have to be taken up in a more thorough study of all the 12th century icons at Sinai.

Towards the end and the turn of the 12th century there is the greatest concentration on iconostasis beams and three of them were made in quick succession. The first, not contained in Sotirious' publication, is still used as such in the Lower Panagia Chapel (Figs. 4-7) ${ }^{21}$. The beam proper, here published for the first time in its entirety, consists of two larger planks which are separated from each other right in the middle of the dodecaorton. But they were not wide enough to contain six scenes each so that at the outer ends separate pieces has to be added which were cut in the upper corners, at the left side (Fig. 4) more than on the right (Fig. 6). This clearly indicates that the beam, which now is inserted into a quite modern iconostasis, was not made for the present place, but apparently at some time put up in a fairly narrow chapel with a tunnel vault. But before the beam was cut to fit such a place it surely must have been in still another chapel where all twelve scenes could be seen intact. This means that the present placing is at least the third, an indication how often icons were shuffled around for centuries in the monastery -a habit which is still in vogue today and which makes it difficult to determine the original location. I need only to point out that according to my own inventory, many icons are no longer in the places where $\mathrm{I}$ have registered them in 1958.

Like the very first beam we discussed above (Figs. 1-2) it shows what we might call the canonical dodecaorton. Whether it shared with this earlier beam the peculiarity that it did not possess a Deesis in the center must be left an open question. If it were included it could only have been on a separate panel and this, right in the middle of the beam, is not a likely proposition. Of the first scene at the left (Fig. 4), the Annunciation, only part of the apparently

20. Sotiriou, Icônes, I, fig. 65; II, pp. 79 ff. K. Weitzmann, The Classical in Byzantine Art as a Mode of Individual Expression, Byzantine Art - An European Art, Lectures, Athens 1966, p. 166 and fig. 126. Weitzmann, The Icon, pl. 22 (in color). Weitzmann et al., The Icon, pl. on p. 57 (color).

21. K. Weitzmann, Three Painted Crosses at Sinai, Kunsthistorische Forschungen. Otto Pächt zu seinem 70. Geburtstag, Salzburg 1972, pp. 26 f. and figs. 7-11. K. Weitzmann, Byzanz und der Westen, Vienna 1984, p. 162 and figs. 27a-b. 

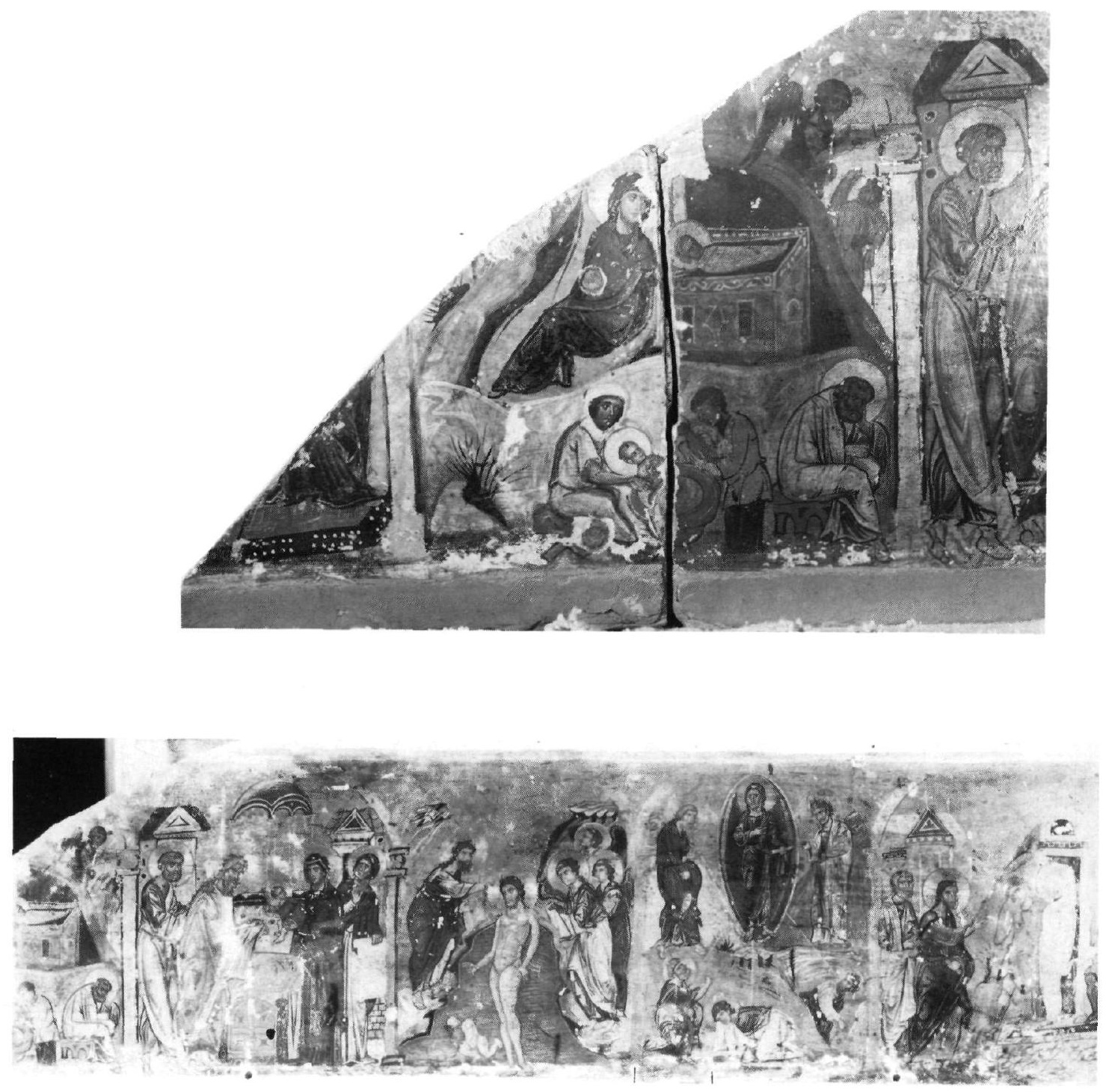

Figs. 4-7. Lower Panagia Chapel. Beam: Dodecaorton. 

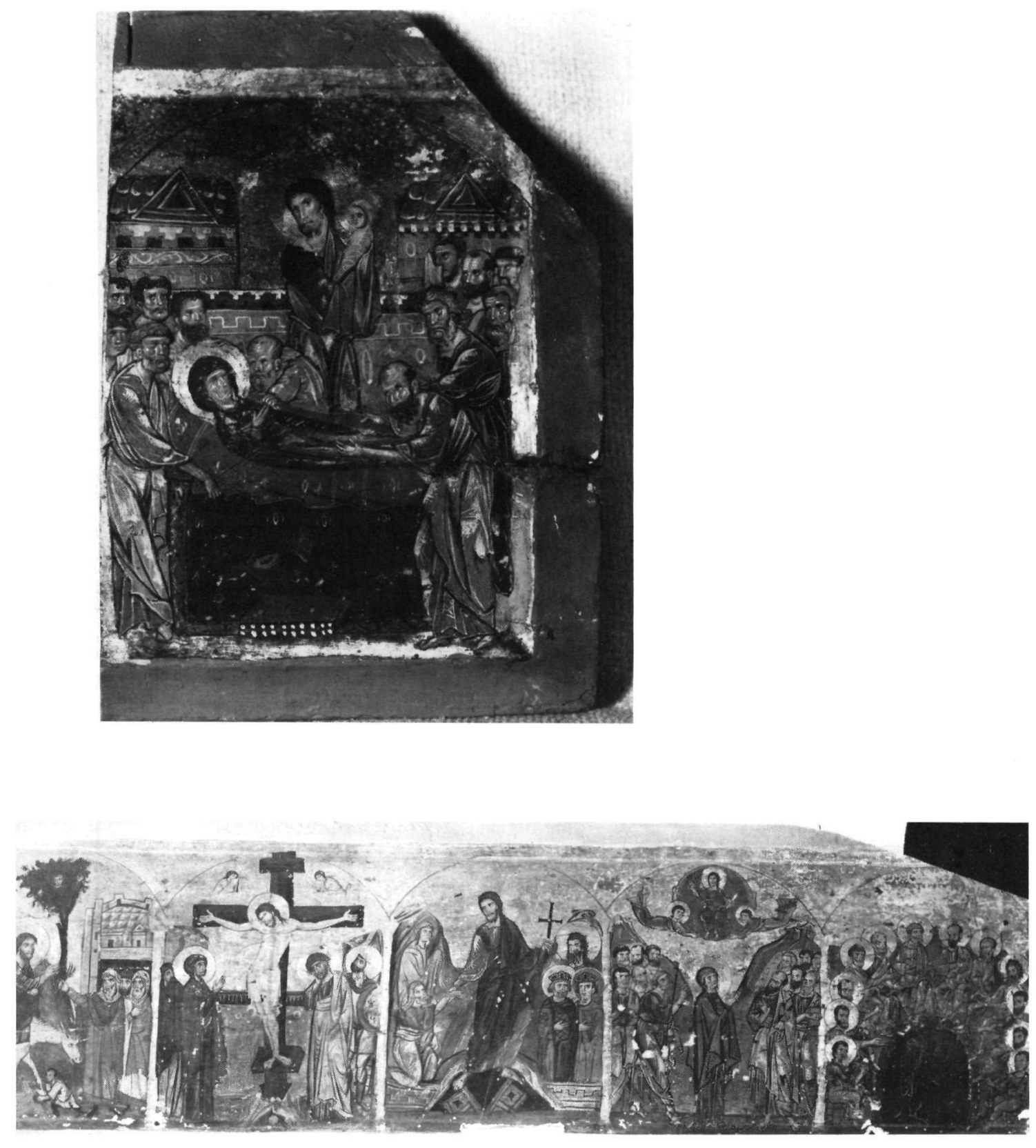
enthroned and not standing Virgin is preserved. Then follows the Nativity, cut through the middle, the left half with the Virgin lying on a mattress being part of the same piece of wood as the Annunciation (Figs. 4-5). In the Presentation in the Temple a very unusual exchange of figures has taken place in that the Virgin offering the Child stands at the right of the altar instead of the left where normally she walks ahead of Joseph, while Simeon here approaching from the left, normally takes the place at the right, being followed by the prophetess Anna. The next scenes, Baptism and Metamorphosis, show the generally accepted iconography of this period and so do the Entry into Jerusalem (Fig. 7), the Crucifixion and the Anastasis. The Ascension likewise is in agreement with the generally accepted Byzantine compositional scheme but has nevertheless some irregular features. Peter, instead of looking up to the ascending Christ points at the Virgin standing in front of him and in his left hand holds, which is quite unusual, a cross staff. In this way the artist seems to have put a special emphasis on Peter as is also the case in the next scene, the Pentecost. Although Peter and Paul, as in good Byzantine tradition, share the center, the frontal pose puts Peter into a position more dominant than that of Paul who turns toward him ${ }^{22}$. In the last scene, the Koimesis (Fig. 6) being a separate panel, there is nothing unusual.

This Koimesis plaque is the only part of the whole beam which is not covered by a heavy darkening varnish and this shows the colors in their original state. They are light and have almost a watercolor effect, being in this respect quite different from the brilliant, enamel-like colors of Constantinopolitan paintings of the Comnenian period. This points to a provincial center whence the artist came who worked at Sinai where as we have claimed, all beams are made ad hoc. Particularly the very light blue of some garments is reminiscent of miniature painting which we should like to attribute to a Palestinian atelier. Moreover, the strong linear quality of the figure design suggests the possibility that this icon painter was at the same time a miniature painter. I have previously pointed out the close connection between our beam and the miniatures of the Penitential Canon of the John Climacus manuscript in the Vatican Library cod. gr. $1754^{23}$, and that both, our beam and this manuscript, should be attributed to Palestine. Since Palestine, like Sinai itself, was dominated by the Crusaders it would explain the iconographical elements which point to some Western influence. There seem to be no other icons at Sinai in this style and this could perhaps, though it must remain a hypothesis,

22. See the discussion about this issue in Weitzmann, St. Peter Icon, pp. $27 \mathrm{f}$. and figs. 27-30.

23. Weitzmann, Three Painted Crosses... (note 21), pp. 27 f. and fig. 10. J. R. Martin, The Illustration of the Heavenly Ladder of John Climacus, Princeton 1954, p. 181 no. 22 and pls. LXXXVII-CVI. 
be explained by the assumption that the artist, surely a Greek, was also a miniature painter.

The Upper Panagia Chapel has likewise a beam inserted in its later iconostasis, a beam which also had not been made for the present location. Of originally 15 scenes under arches only ten were taken over. The first five (Figs. $8-9$ ), as in one of the beams we discussed earlier (p. 70), start with the Birth of the Virgin and her Presentation in the Temple, preceding the dodecaorton proper, to be followed by the Annunciation to the Virgin, the Nativity and Christ's Presentation in the Temple. Then there is a gap and the cycle continues after that with the last five scenes of the dodecaorton from the Crucifixion to the Koimesis (Figs. 11-14). But at the same time when the central section was omitted, the ends of the beam have, in a haphazard manner, some icons added which have nothing to do with the program of the beam: at the left one with the Forty Martyrs of Sebaste and at the right a diptych with a bust of the Virgin and Saints and an icon of St. Cornelios. The central part must have contained the scenes from the Baptism until the Entry into Jerusalem and -in analogy to other beams- a Deesis in the center. This omitted panel still exists and is now kept in the chapel of Constantine and Helen in the basilica (Fig. 10). It fits in the figure style, in the system of the decoration of the arches and the disks in the spandrels designed by the roughening of the burnished gold so that it becomes visible only when the light falls on it, in the measurements -the average height is between 38 and $39 \mathrm{~cm}$.and most of all in its iconography comprising the scenes which make the dodecaorton complete. I had previously recognized that the scene of the Nativity (Fig. 9) was by the same hand as the beam in the basilica (Fig. 10) but had assumed that this artist had been working on two different beams, first as apprentice so to speak with older masters and then independently on a second beam, of which only the piece in the basilica was supposed to have survived. This idea has now to be abandoned and it turns out that the most outstanding of all the Sinai beams has come down to us in its entirety.

The beam in the Upper Panagia Chapel had never been made known before as a whole: the first and the third scenes are unpublished and the other eight were only published piecemeal ${ }^{24}$, whereas the center part with the scenes from Baptism to the Entry into Jerusalem had been made known first by Sotirious' publication, and subsequently in other places $^{25}$. The central Deesis and four

24. Weitzmann et al., Frühe Ikonen, pp. XIV ff., LXXXII, pls. 32 (Ascension); 33 (color, Anastasis); 35 (color, Koimesis). Weitzmann, Byzantium and the West, pp. 59 and passim and figs. 13, 15, 16, 18, 28. Weitzmann, Ikonen, pl. 10 (color, Virgin in the Temple). Weitzmann et al., The Icon, pl. on p. 63 (color, Nativity).

25. Sotiriou, Icônes, I, figs. 112-116; II, pp. 111 ff. Weitzman n, Byzantium and the West, pp. 60 and passim and figs. 19, 21, 23. Weitzmann, The Icon, pl. 31 (color, Lazarus). 

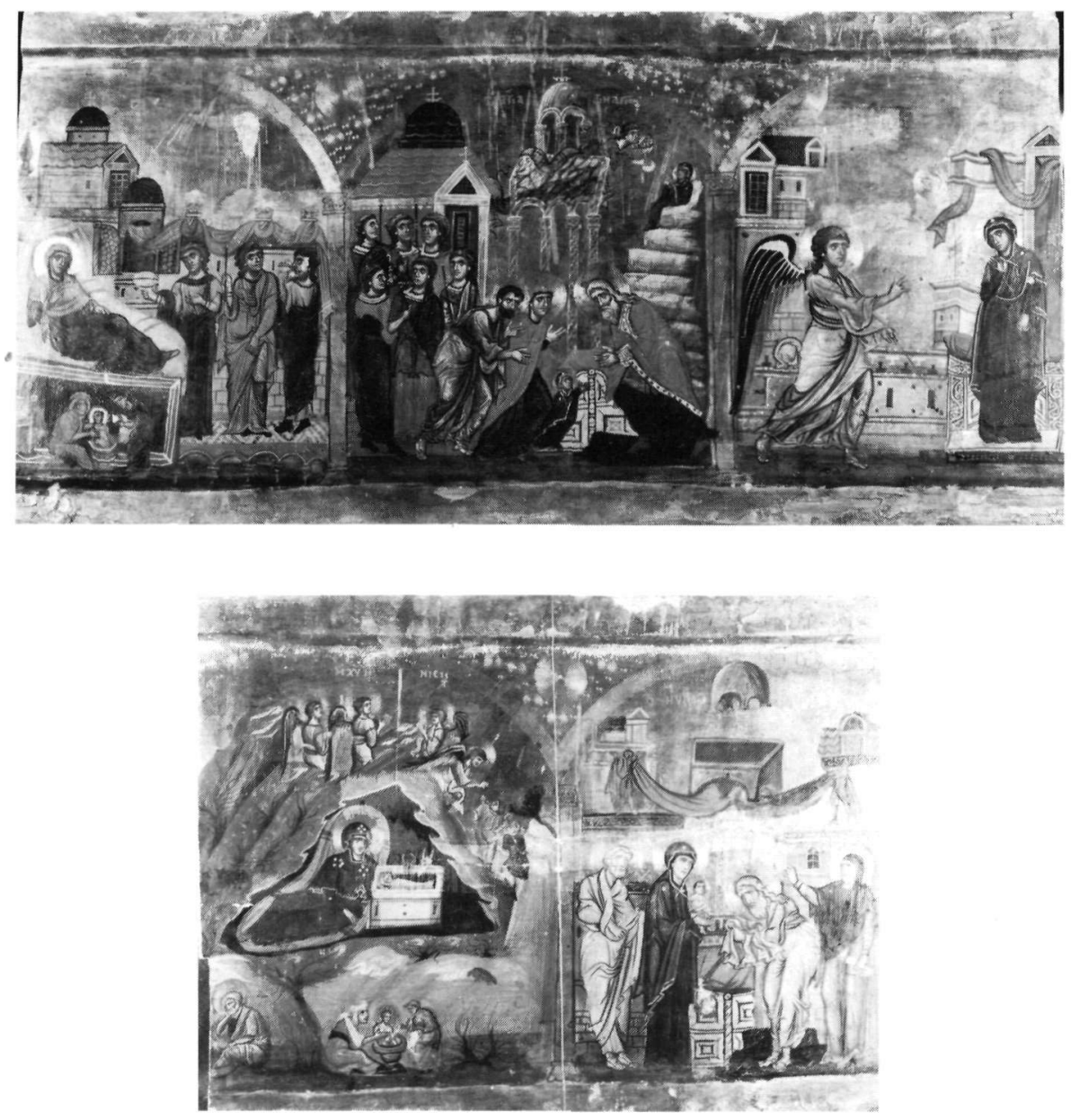

Figs. 8-9. Upper Panagia Chapel. Beam: 8. Two Virgin scenes and Annunciation, 9. Nativity and Presentation in the Temple.

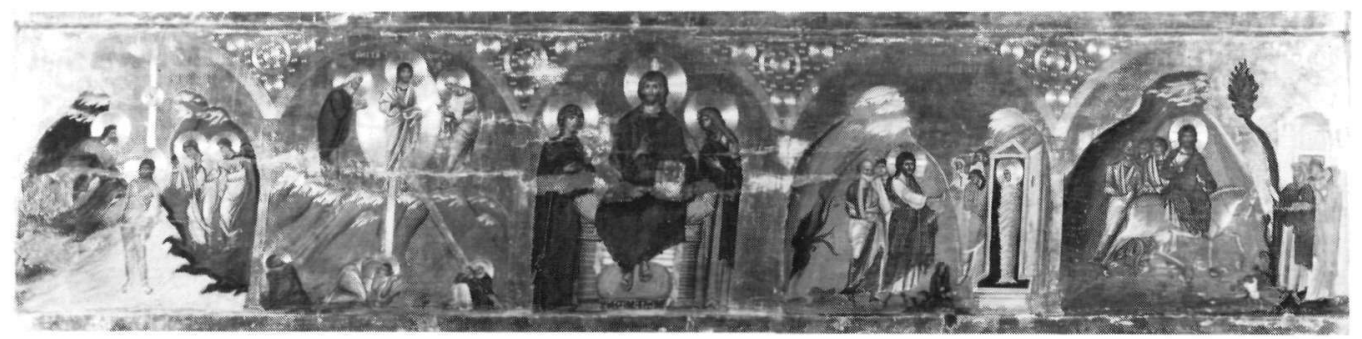

Fig. 10. Basilica. Chapel of Constantine and Helen. Beam: Baptism to Entry in Jerusalem and Deesis. 
flanking scenes occupy one plank and this suggests that the rest of the beam consisted originally of two more planks each likewise with five scenes. But for reasons we do not know, they were cut up when they were fitted into the new iconostasis in such a way that the first plank was cut between the third and the fourth scene (Figs. 8-9), and the second plank even more so, having left only the first two scenes joined (Fig. 11) and the other three sawed up into single panels (Figs. 12-14).

In my previous writings on the beam of the Upper Panagia Chapel I called it the "Three master-beam", since three distinct artists can be distinguished. The first three scenes (Fig. 8) are the work of a painter whom I should like to call "the traditionalist", an artist who adheres to an established iconography and the typical Late Comnenian style. The figures appear restless, as Anna in childbed in the Birth of the Virgin, or as Joachim and Anna, the Virgin and the High Priest rushing forward as if in a hurry in the Presentation scene. Moreover the architecture gets more complex and hanging draperies as in the Annunciation create undulated movements. All this is expressed by a strong linear design. The next scene, the Birth of Christ (Fig. 9), shows a totally different style which is a break with the Comnenian tradition. This artist tries to achieve expression by color rather than by line and instead of the traditional local colors he uses orange, ochre and flickering highlights on craggy tops of mountains. Moreover, in order to give greater prominence to the landscape he reduces the scale of the human figures. We might call this painter the "innovator". But the next scene, the Presentation of Christ in the Temple, is again a work of the "traditionalist", where the restlessness is clearly expressed in the drapery of Simeon eager to receive the Christ child. The very fact that Nativity and Presentation are on the same piece of wood can only mean that the two artists worked side by side and that no time gap had taken place whereby the "innovator" might have succeeded the "traditionalist" at some later time. We deal here obviously with a problem of generation where a younger artist works side by side with an older who adheres to a style in which he had been trained. But after the Presentation the "innovator" takes over and has the whole central plank to himself (Fig. 10). In the scenes of the Baptism and the Metamorphosis the innovative landscape treatment is particularly obvious and the flickering highlights on the mountain caps are supportive of the inner restlessness of the figures. Moreover, in the Metamorphosis he reveals himself as also an innovator of iconography, creating entirely new and unique types for the three apostles struck by the light of Mount Tabor. The emphasis on the landscape is evident also in the encompassing pyramidal mountains in the Raising of Lazarus and Entry into Jerusalem scenes and their inner glow of the orange color has a strange emotional effect on the beholder. However, in the central Deesis the artist works in a quite different mode. Here 

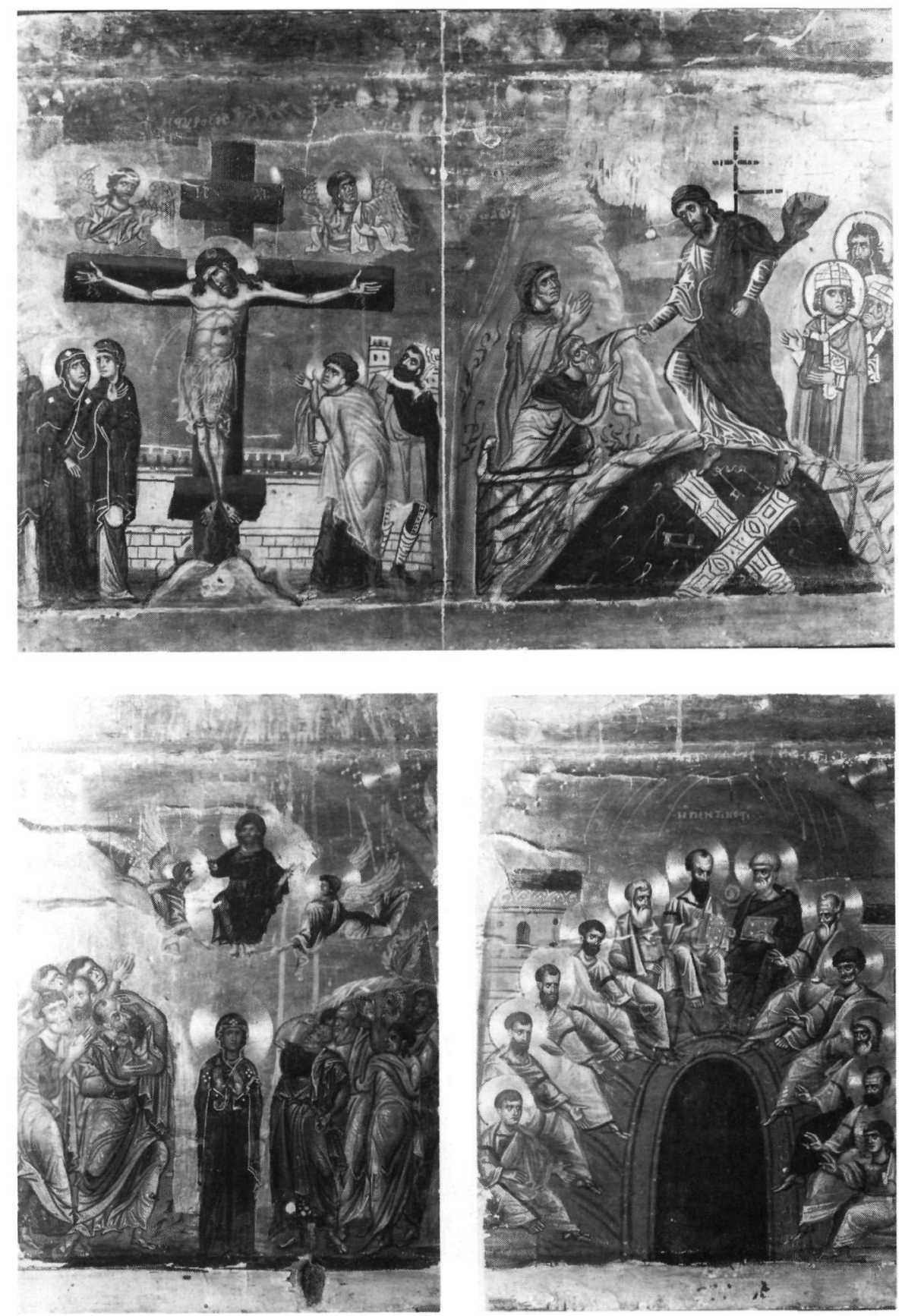

Figs. 11-13. Upper Panagia Chapel. Beam: 11. Crucifixion and Anastasis, 12. Ascension, 13. Pentecost. 
he clings to a strong hieratic rendering of a motionless Christ enthroned, flanked by the Virgin and John the Baptist in stiff poses. All the painterly richness this artist is capable of is suppressed for the sake of adhering to a generally accepted and thus unchangeable iconography. Had the Deesis survived as a single panel one might, on mere stylistic grounds, not have recognized it as part of the same ensemble.

In the third plank the first two scenes, the Crucifixion and the Anastasis (Fig. 11), are clearly once more the work of the "traditionalist". The contorted pose of John in the Crucifixion is once more typical of his linear expressionism and so are the rushing forward poses of Christ and Adam in the Anastasis. The next scene is perhaps the

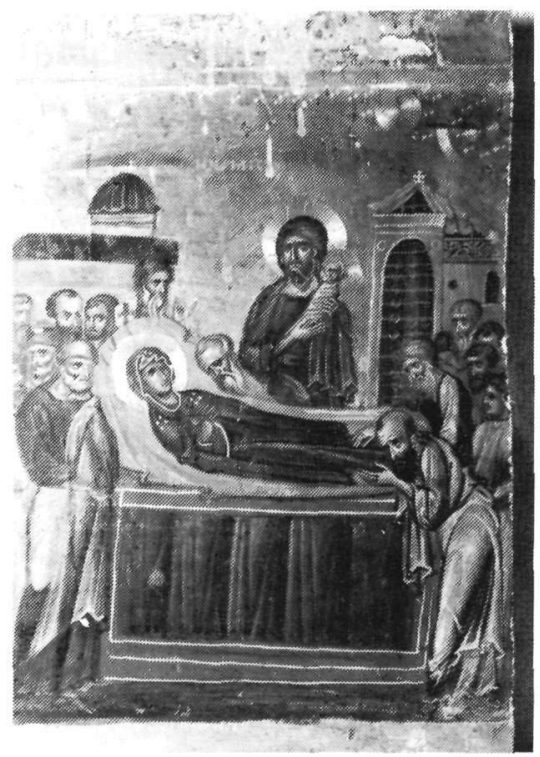

Fig. 14. Upper Panagia Chapel. Beam. Koimesis. most interesting one of the whole beam because here three artists have been working together on the representation of the Ascension. The Apostle group at the lower left, headed by Paul, is clearly the work of the "traditionalist" while the group at the right, headed by Peter is by another hand. It is characterized by more slender figures with markedly small heads. He is an artist who leads the late Comnenian mannerism to its extreme and may therefore be called the "mannerist". On the basis of figure scale the Virgin must also be ascribed to this hand, although the stiff frontal hieratic pose is free of mannerism. This section of the Ascension looks almost like an intrusion, and we have been unable to identify this hand in any other scene or icon. The ascending Christ is clearly the work of the "innovator" who completes the beam with the Pentecost, which with Paul in the center and Peter pushed to the side, clearly reflects an anti-Roman sentiment ${ }^{26}$, and the Koimesis.

When I first published the parts of the beam of the Upper Panagia Chapel I took them as a work primarily of a traditional artist, into which a young artist reflecting a new painterly style had intruded. But now, with the knowledge that the central part believed to have been lost has been identified, the picture 
looks quite different. Now it appears that from the very beginning the "innovator" was the leading master who had reserved for himself the whole central plank, added in the left one the Nativity and in the right one first completed the Ascension and then painted the Pentecost and Koimesis. This means that he took for himself more than half of the fifteen units. Moreover, the "innovator" was apparently at that time the head of a most productive workshop at Sinai to which, among other works, the set of the huge calendar icons must be ascribed about which we will have more to say later on (p. 107 ff.).

In addition to the six beams discussed so far, all of them executed within a hundred years from the early 12th to the early 13 th centuries, there seems to have existed still another type of beam which consisted of single panels. When beams of this type were dissolved, their individual panels are understandably difficult to identify as belonging to a larger context. Yet in two cases, the existence of such beams can be made likely. Chatzidakis proposed that an icon with the bust of St. Thomas ${ }^{27}$ be part of a beam which contained the twelve apostles as single panels. This is not impossible, but if this was the case, it must have been a beam of rather unusually small size, since the icon is only $17.2 \mathrm{~cm}$. high while the normal height of a beam is between 30 and $40 \mathrm{~cm}$. Besides, we believe that Chatzidakis dated the Thomas plaque too early, proposing the 10th-11th century. I myself proposed a 12th century date for it $^{28}$ and attributed it to a Western, i.e. a Crusader artist.

There is still another apostle icon of Sinai which has a good chance of having once belonged to an apostle beam consisting of single panels. It represents a bust of Peter ${ }^{29}$ and in this case three reasons can be adduced in favor of having once belonged to an apostle beam as we envisage it: 1) it has the normal height for a beam $(43.8 \mathrm{~cm}) ; 2$.$) it actually is today inserted into an$ epistyle in the St. George Chapel next to the first beams we discussed (p. 66), and 3) it was apparently used as the model for the Peter in the apostle beam of a Crusader artist which we shall discuss later on. We do not know for sure when the beam type with single panels was invented. But since to this system belongs the future whereas the type of beam with a continuous frieze on planks is gradually dying out, it seems to us that the former gradually replaced the latter. So unless evidence shows up to the contrary, we have our doubts about a 10th century origin of the single panel beam.

At Sinai only two beams are preserved of the advanced 13 th century, i.e. at

27. Chatzidakis, L'évolution, p. 164 and pl. XXVI, 2.

28. K. Weitzmann, Die Malerei des Halberstädter Schrankes und ihre Beziehung zum Osten, Zeitschrift für Kunstgeschichte 41 (1978), p. 280 and fig. 31.

29. Weitzmann, St. Peter Icon, p. 7 and fig. 4. 
a certain distance of time from those discussed so far, and both are painted by Western, i.e. Crusader artists. One of them, already published by the Sotirious $^{30}$ and subsequently mentioned on various occasions by myself ${ }^{31}$ and others $^{32}$, represents as half figures under pointed arches, the Deesis flanked by Peter and Paul, the four evangelists and the soldier saints George and Procopios. The whole beam consists of a single piece of wood on which all eleven figures could be accommodated; it must have been made for a chapel of small size. There was in the monastery a chapel called "St. Catherine of the Franks" and it is possible that the beam was made for this chapel but this is not sure because there exists still another beam made by a Crusader artist and there may actually have been two chapels at this time for the Latin service. Whatever chapel it was in which our "apostle beam" was part of an iconostasis, it must have been known through the centuries as the place for the Latin service because in 1530 one visitor scratched a graffito on the beam: Fra Ludov(ico) di Luxina (?) fuit hic. The style with its sharp design and high degree of plasticity is the product of a larger workshop which worked at Sinai in the second half of the 13th century and whose chief product is a monumental bilateral icon with the Crucifixion on the front and the Anastasis on the back ${ }^{33}$. This latter icon is on its part closely related to two panels in the Museo Correr in Venice depicting in bust form John the Baptist and St. Andrew ${ }^{34}$ and from this I concluded that the painters of the Crucifixion icon and the Apostle beam were Venetians. Recently Otto Demus has gone a step further ${ }^{35}$ and attributed the Sinai Crucifixion to the same master as the Correr panels thus making the Venetian origin of the Sinai workshop even more convincing. Demus calls him the "Correr Master" but I prefer to call him the "Crucifixion - Anastasis Master" after what I consider to be his most important work. Demus pointed out that the John the Baptist panel in the Correr Museum has a date 1281

30. Sotiriou, Icônes, I, figs. 117-124; II, pp. 112 ff.

31. K. Weitzmann, Die byzantinischen Elfenbeine eines Bamberger Graduale und ihre ursprüngliche Verwendung, Studien zur Buchmalerei und Goldschmiedekunst des Mittelalters. Festschrift K. H. Usener, Marburg 1967, p. 16 and fig. 7. Weitzman n, St. Peter Icon, p. 24 and figs. 25, 32. Weitzmann, Ikonen, pl. 14 (color, Matthew); Weitzmann et al., The Icon, pls. on pp. 229-231 (color, Matthew and Paul).

32. O. Demus, Zum Werk eines Venezianischen Malers auf dem Sinai, Byzanz und der Westen, Studien zur Kunst des Europäischen Mittelalters, Vienna 1984, p. 136 and fig. 11 (St. Paul).

33. Weitzmann, Thirteenth Century, pp. 183 ff. and figs. 5-6. Weitzmann, Grusader Kingdom, p. 64 and figs. 26-28; Weitzmann, The Icon, pl. 38 (color, Crucifixion); Weitzman n et al., The Icon, pls. on pp. 225-226 (color, Anastasis); Demus, op. cit., pp. 131 and passim, figs. 3-5.

34. Weitzmann, Crusader Kingdom, p. 64 and fig. 25 (here further bibliography); De mus, op. cit., pp. 131 and passim, figs. 1-2.

35. Demus, op. cit., p. 140. 
which is by a later hand, but may faithfully repeat the original date. This makes me think that the Sinai beam and panels in this style which I dated repeatedly in the third quarter of the 13th century may possibly be a little later and it would perhaps be safer to date them more broadly into the second half of the 13th century, thus not excluding the last quarter.

The Venetian painter, who was not accustomed to paint an iconostasis beam, adopted this form while working at Sinai in an orthodox surrounding. There actually is some evidence that he may have used a Byzantine apostle beam which was in the monastery as a model. As mentioned above (p. 80) a 12th century icon with a bust of Peter which most likely was part of an iconostasis beam in single panels suggests that there was such a type of beam available, but the connection is even more direct: we deal with the very same type of Peter with a double row of locks above the forehead and the way in which he holds both a scroll and keys on a string is very similar. Such details make it quite certain that this Peter panel was the actual model for the Peter of the beam. However, in some of the other apostle figures the Venetian painter made adjustments to the Western tradition. He depicted John the Evangelist black-haired who in Byzantine art is always white-haired and in the West beardless.

The second Crusader beam at Sinai is of quite a different character (Figs. 15-17) $)^{36}$. Like the Byzantine ones it represents the dodecaorton and in addition to the twelve a thirteenth scene, the Last Supper. Although we do not have a parallel for this intrusion in any Byzantine beam, it could well have existed in one no longer extant. In Byzantine art the Last Supper occurs regularly together with the Washing of the Feet. They illustrate the MaundayThursday readings preceding the Good Friday and are of a liturgical importance equal to the Passion readings. Actually there is at Sinai a panel with the Washing of the Feet from the 10th century which we believe to be a part of an iconostasis beam and, if so, would actually be the earliest fragment of any painted beam ${ }^{37}$. Thus it is not impossible, though it has to remain a hypothesis, that the Crusader painter had seen at Sinai a 10th century beam which enclosed next to the Washing of the Feet the Last Supper. On the other hand the Crusader painter omitted the Deesis in the center, which in a Byzantine beam would normally have been between the Raising of Lazarus and the Entry into Jerusalem.

The artist, while relying as a whole on the Byzantine dodecaorton, shows in

36. Here published for the first time complete. Weitzmann, Thirteenth Century, pp. $181 \mathrm{ff}$. and figs. 3-4 (Crucifixion and Pentecost); Weitzmann, Crusader Kingdom, pp. 62 ff. and figs. 22-24 (Crucifixion, Nativity, Koimesis); Weitzmann, St. Peter Icon, p. 26 and fig. 28 (Pentecost). Weitzmann et al., The Icon, pls. on pp. 222-224 (color, Nativity).

37. Weitzmann, Sinai Icons, I, pp. 91 ff., B56 and pls. XXXV and CXI; Chatzidakis, L'évolution, p. 172 and pl. XXVI, 1. 

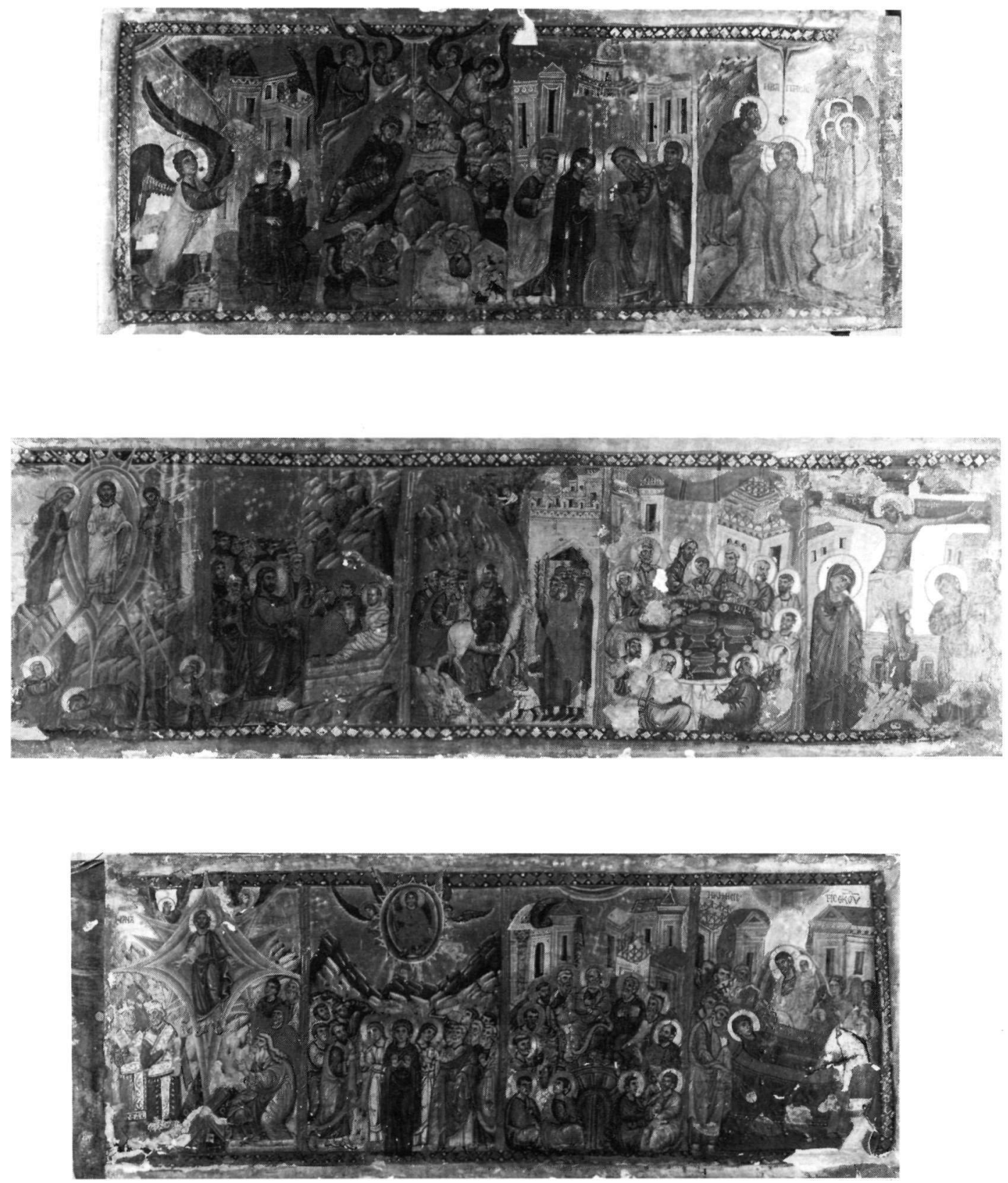

Figs. 15-17. Upper Panagia Chapel. Beam: Annunciation - Baptism, Metamorphosis-Crucifixion, Anastasis-Koimesis. 
some details considerable independence from the Byzantine iconography, partly falling back on the Western tradition, partly being an innovator. In the Annunciation, in order to emphasize the element of surprise, the Virgin, absorbed in spinning, sits with her back to the angel, but turns her head around, thus creating a lively contrappostic pose. A unique feature we meet in the Nativity where one of the Magi is characterized as a Mongol. I have elsewhere ${ }^{38}$ suggested that this Mongol portrays General Kitbuqa who, after St. Louis had sent in 1249 an embassy to the Great Khan in Karakorum, was dispatched by the latter to combat as an ally of the Crusaders, the Moslems. However in 1260 Kitbuqa was defeated and decapitated by the Mameluk General Baibars. The reason to represent Kitbuqa as one of the three Magi is easily enough explained by the fact that he was not only himself a Nestorian Christian but had claimed to be a descendant of one of the Magi. Thus the beam becomes an important historical document which could have been painted only after 1249 and most likely before 1260 , the decapitation of Kitbuqa. The Presentation in the Temple and Baptism follow essentially the Byzantine tradition and so does the Metamorphosis except that Moses, always beardless in Byzantine art is here, as typical of all Crusader art, depicted with a dark beard and that the strongly ornamentalized mandorla, which about that time begins to become elaborate by multiplying the ovals and emphasizing the rays, takes the unusual pointed form at the bottom and by turning the rays to spikes. The Raising of Lazarus shows decidedly Western elements by depicting him baldheaded and bearded and seated upright on top of a sarcophagus instead of standing erect in the opening of an aedicula. Then the rather conventional Entry into Jerusalem is followed by the Last Supper which has very distinct Western iconographical features. The sitting around the table, with some apostles in front of it and seen from the back, occurs since the 11th century also in Byzantine Last Supper scenes ${ }^{39}$, but what is utterly nonByzantine is the placement of Christ with John, the beloved disciple, on his bosom in the center behind the table and, instead of lying on a couch to the left, being flanked by Peter with the keys in his hands and Paul holding a codex, to single out only the most salient points. In the Crucifixion the most distinct features are the mourning gestures of the Virgin and John who touch with their thumb and little finger their mouth and nose, a characteristic which occurs also in the above-mentioned Crucifixion of the "Crucifixion - Anastasis" master, the head of the Venetian atelier at Sinai (p. 81).

38. Weitzmann, Crusader Kingdom, p. 63.

39. One of the earliest and best examples is in the 11th century lectionary, Mt. Athos, Dionysiou cod. $587 \mathrm{~m}$ fol. 52r. S. M. Pelekanidis et al., The Treasures of Mount Athos. Illuminated Manuscripts, I, Athens 1973, fig. 224 on p. 183. 
The Anastasis represents a very rare Byzantine type in which, contrary to the usual compositional scheme according to which Christ drags Adam out of Hell like Heracles the Cerberus, he is depicted standing frontally with stretched out arms while Adam and Eve down below raise their arms toward Christ who cannot be touched by them. One of the earliest extant examples of this type is in the 11th century lectionary in the Athos monastery of Iviron, cod. 1 fol. $1 v^{40}$. But while in this miniature Christ is standing on top of the hillock which includes hell, in the beam he is lifted up as in an Ascension. Moreover, in the former Adam and Eve kneel left and right of the hell as is usual for this type of composition, whereas in the beam both Adam and Eve are together one above the other on one side as is common in the normal Byzantine scheme with the dragging Christ. Thus it becomes clear that the Crusader painter mixed the iconography of two compositional schemes which are distinct in Byzantine art. Moreover, Christ stands in an aureola even more spiky than the one in the Metamorphosis. The Ascension with the Orant Virgin flanked by two angels standing in the midst of the Apostle group follows quite faithfully the Byzantine tradition, whereas in the Pentecost the artist makes a very conscious deviation from it. In the Byzantine tradition Peter and Paul share the center, but in the beam Peter occupies it alone, thus propagating pictorially the primacy of the Roman Papacy ${ }^{41}$. The Crusader artist painting at Sinai must have been acquainted with the various beams in this place so that the deviation from the Byzantine tradition must be viewed almost as an act of defiance. Also in the last of the feast pictures, the Koimesis ${ }^{42}$, the artist makes changes in the iconography which a Byzantine artist would not have made and might even have objected to. Of the assembled twelve apostles only the left group behind the Virgin's bier is depicted, while the one at the right is replaced by a group of archangels, one offering the globe to the Virgin. Angels as such are not uncommon in a Byzantine Koimesis, but here they are candle bearers, fitting the funerary setting. The orb is offered to the "Queen of Heaven" who is a Western concept and thus the artist once more made a conscious alteration of the otherwise accepted compositional scheme.

This beam gives a particularly clear insight into the mentality of a Crusader artist who depicts on an iconostasis beam a Byzantine dodecaorton with great empathy, but at the same time asserts his Western convictions by making conscious changes in the iconography. He was, we believe, a Venetian whose

40. The miniature is not published in the corpus of Pelekanidis (note 39), II, and presumably was cut out and is lost. But it is published in the earlier publication by A. Xyngopoulos, Évangiles avec miniatures du monastère d'Iviron, Athens 1932.

41. Weitzmann, St. Peter Icon, p. 26 and fig. 28.

42. Weitzmann, Crusader Kingdom, p. 64 and fig. 24. 
style differs somewhat from that of the Apostle beam of the "Crucifixion Anastasis Master". His figures are more painterly and have their closest affinity with the diptych of King Andrew of Hungary in Bern ${ }^{43}$. Both beams are about contemporary and it is difficult to say which is the earlier. However, since the beam with the feasts suggests time limits between 1249 and 1260 on historical grounds, and the apostle beam a date around 1281, the presumed date of the Correr John the Baptist icon, the former may have preceded the latter by a few years. But since both dates are only approximate, the question of the sequence must be left open.

Nothing characterizes the flourishing period at Sinai from the early 12th to the early 13th century so well as the series of the iconostasis beams. Beams with a painted feast cycle had existed before as indicated by the abovementioned panel with the Washing of the Feet from the 10th century, but none is left at Sinai of the 11th century and after the early 13th century the two Crusader beams from the second half of the 13th century almost seem to be stragglers. After that period painted beams apparently went out of fashion, a phenomenon which can be explained in a twofold way: either no more additional chapels were built and in need of beams, or if new ones were erected they might have used the type of individual plaques which, once separated from the original context, are no longer recognizable as such. Perhaps both explanations are possible. It should, however, be mentioned in passing that in the second half of the 15th century, there was a revival of painted beams. One is a fragment with three scenes from the Life of the Virgin under sculptured arches, in which her Birth and Presentation is preceded by an Annunciation to Anna, and the other is complete in three parts representing the Deesis and the twelve apostles enthroned. I mention them here because they both obviously copy earlier models, reflecting the style of the 12th or early 13 th century. This shows clearly the high esteem in which works of this period were held when after the fall of Constantinople in 1453 there was at Sinai a revival of the art of these earlier centuries.

\section{B. THE INTERCOLUMNAR ICONOSTASIS ICONS}

It is to be expected that the same iconostasis which had the epistyle decorated with painted beams had also icons in the interstices between the pillars supporting the epistyle. But since not a single iconostasis of the 12th or 13th centuries has been preserved at Sinai in its original state one faces the difficulty whether one will be able to identify among the great mass of icons 
those which were destined for this special placement. Chatzidakis clearly recognized this difficulty when he discussed this very problem, not specifically for Sinai but in general. He raised the question in connection with a few famous Virgin icons without however coming to a firm conclusion as to their original placing ${ }^{44}$.

One possible approach to this problem is the search for those icons which form pairs and never existed single. Such pairs are, e.g., Peter and Paul, not in frontal position but turned to each other. We dealt with this problem in our study of the Peter icon at Dumbarton Oaks ${ }^{45}$ and discussed in it several such pairs existing at Sinai, suggesting that they once were part of an iconostasis. At the time when so many beams were painted there was obviously a great demand for large intercolumnar icons like these sets of busts of Peter and Paul.

But since Peter and Paul do not fill a whole iconostasis the immediate question is: what were the other icons? To one pair of Peter and Paul icons, the set now preserved in the Chapel of the Holy Apostles (Fig. 18) ${ }^{46}$, there can be attached an icon with the bust of the Archangel Gabriel (Fig. 19) which, because of its bad condition, would no longer be exhibited in one of the chapels but relegated to the magazine. In style and measurements ${ }^{47}$ it is so close to the Peter and Paul icons that there can be no doubt that it belongs to the same set. From this it follows that there must have been a counterpart with a bust of the archangel Michael as there are several such sets of archangel icons in bust form preserved at Sinai (Fig. 20). These icons, then, are clearly part of a Grand Deesis where the busts with Christ, the Virgin and John the Baptist were flanked by those of the archangels and they in turn by the Princes of the Apostles. However, the question is whether there were actually three more icons representing busts of Christ, the Virgin and John the Baptist in existence that belonged to this particular set? If this were the case then, because an even number is required, since the center is the Royal Doors which separate the icons in two even halves, one more icon would have to be assumed, presumably of some saint. Such full sets did indeed exist but must not in each case necessarily be assumed because, as we have seen, the Deesis is frequently in the center of the beam and thus would take a very central position directly above the Royal Doors. It is hardly likely that in such a case the Deesis would be repeated within an iconostasis as intercolumnar icons. Perhaps future search among the Sinai icons will clarify this point, but for the moment this question has to be left open.

44. Chatzidakis, L'évolution, pp. $182 \mathrm{ff}$.

45. Weitzmann, St. Peter Icon, pp. 33 ff. and figs. 33-40.

46. Ibid., p. 33 and fig. 36 . It measures $64.4 \times 49.6 \mathrm{~cm}$.

47. Unpublished, $64.4 \times 49.6 \mathrm{~cm}$. 


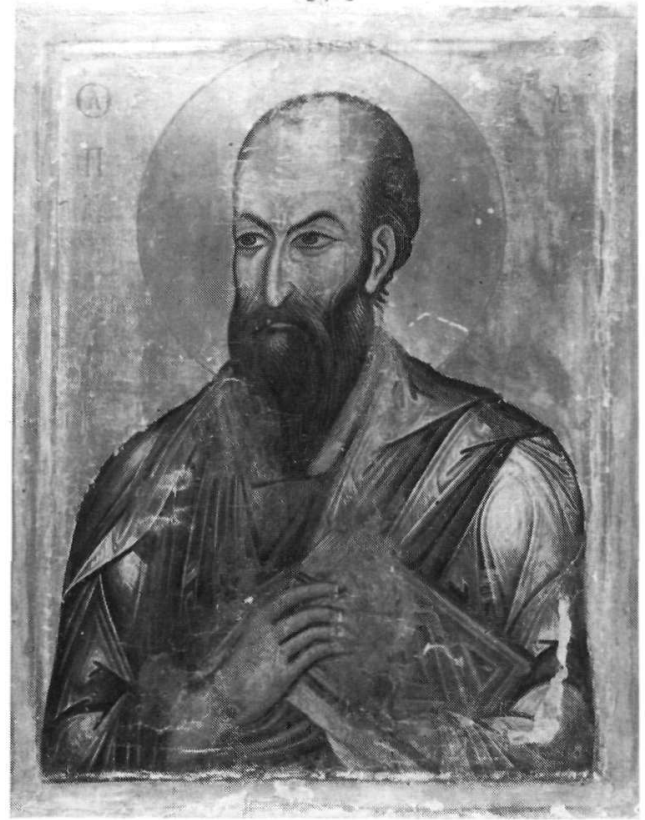

Fig. 18. Chapel of the Holy Apostles. Bust of Paul.
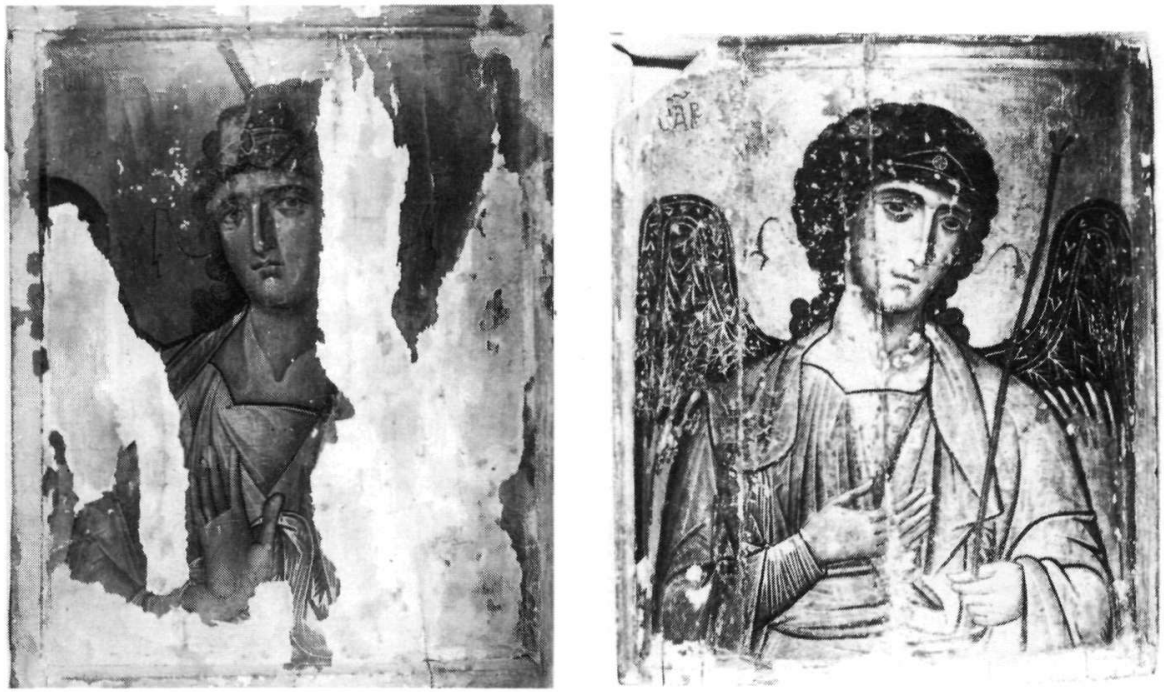

Fig. 19. Old Library. Bust of Gabriel.

Fig. 20. Gallery. Bust of Michael. 
A bust of Christ must not necessarily be a part of a Deesis and could exist, as in many cases it did, as a self-contained icon. Only if some Virgin or John the Baptist icon could be found in the same style and with the same measurements would we be on sure ground that a Christ icon is indeed part of a Deesis. There is an icon with a bust of Christ, kept under glass in a cupboard in the New Library (Fig. 22) ${ }^{48}$ which when I saw it was heavily overpainted, but now has been cleaned. On the basis of its style it can be attributed to the turn of the 12th-13th century. Close in style and measurement is a Virgin in the pose of an intercessor (Fig. 21$)^{49}$ kept in the Gallery and doubtless part of the very Deesis of which the above-mentioned Christ must, then, have been the center. The Virgin icon is heavily varnished but not overpainted and this suggests that the two icons were already separated when presumably Cornaro in the 18th century overpainted the Christ. But in spite of overpaint and varnish the facial features, eyes, nose and mouth are so much like those of Christ that there can be little doubt about their being part of the same Deesis of which John the Baptist is either lost or has not yet been traced. This Deesis was flanked by the busts of the archangels Michael (Fig. 20) and Gabriel both of whom are preserved and like the Virgin are exhibited in the Gallery and have been published ${ }^{50}$. Once more style and measurements agree ${ }^{51}$. The facial features and the slightly melancholic expression of the two angels agree very well with those of the Virgin and leave no doubt about their being a part of the same ensemble. The question still unsolved is whether the archangels were flanked on their part by a set of icons with the busts of Peter and Paul. Unless some evidence should show up, this question must be left undecided because in principle they could, but must not necessarily, be part of this set.

In one instance, two icons of these types are still serving their original function and decorate an iconostasis although it is a later one and not the one for which they were originally made. One represents a bust of John the Baptist in the pose of intercessor (Fig. 23) $)^{52}$ and the other a bust of St. Paul (Fig. 24) ( $^{53}$. In order to fit into the iconostasis of the Symeon Stylites Chapel, a side chapel opening into the south aisle of the basilica, they were brutally cut down on all four sides and awkwardly placed on top of the icon depicting Symeon Stylites within the same opening. Though looking small in the present state, they

48. Unpublished.

49. Unpublished.

50. Sotiriou, Icônes, I, fig. 72; II, p. 87.

51. Christ: $53.8 \times 46 \mathrm{~cm}$; Virgin: $54.5 \times 45.7 \mathrm{~cm}$.; Michael: $53.8 \times 44.2 \mathrm{~cm}$.

52. Forsyth - Weitzmann, Church and Fortress, pl. XCIII B. The reduced measurements are $35.5 \times 23.5 \mathrm{~cm}$.

53. Weitzmann, St. Peter Icon, p. 35 and fig. 39. The reduced measurements are $34.8 \times 22.2$ $\mathrm{cm}$. 


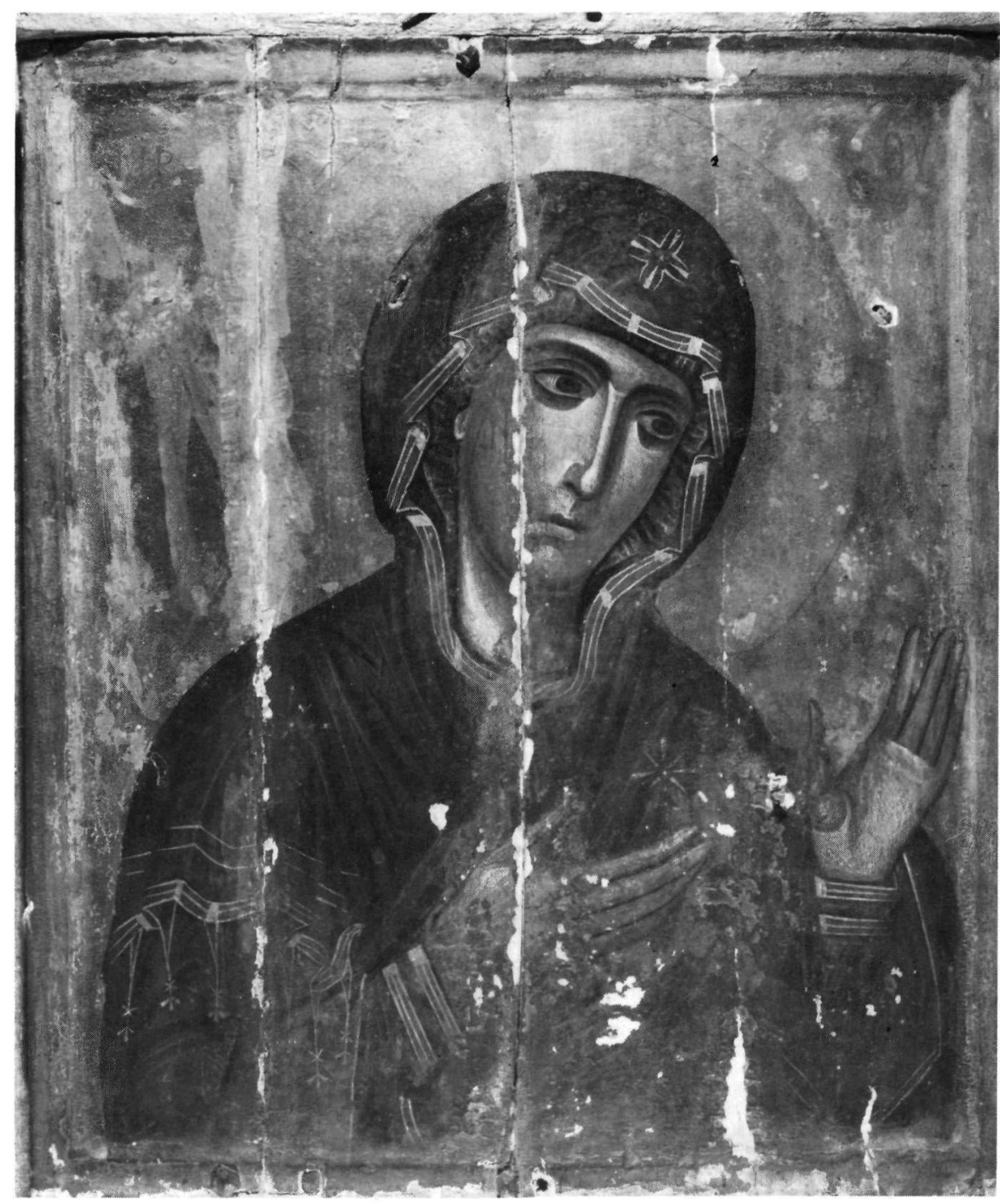

Fig. 21. Gallery. Bust of Virgin. 


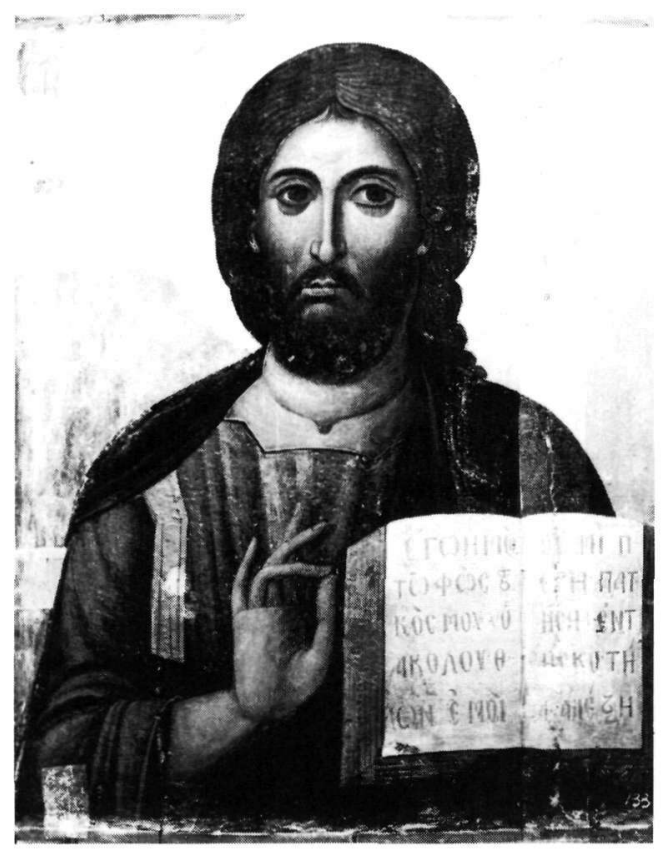

Fig. 22. New Library. Bust of Christ.

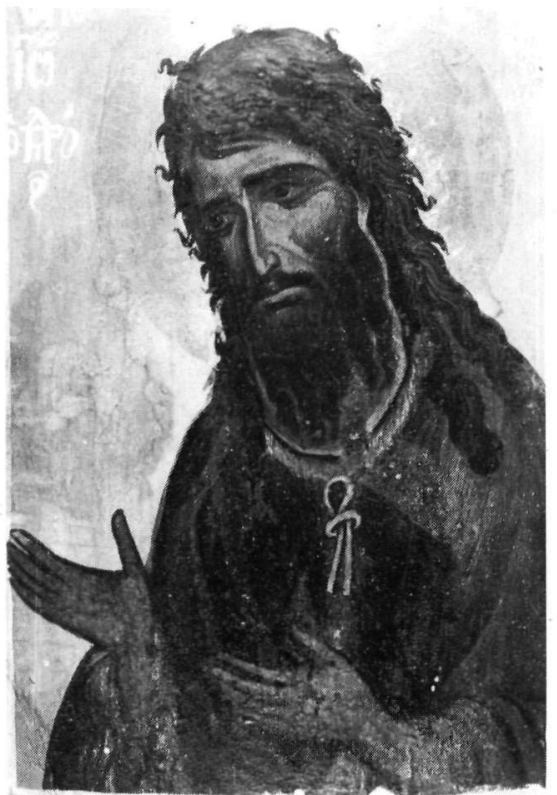

Fig. 23. Chapel of Symeon Stylites. Bust of John the Baptist.

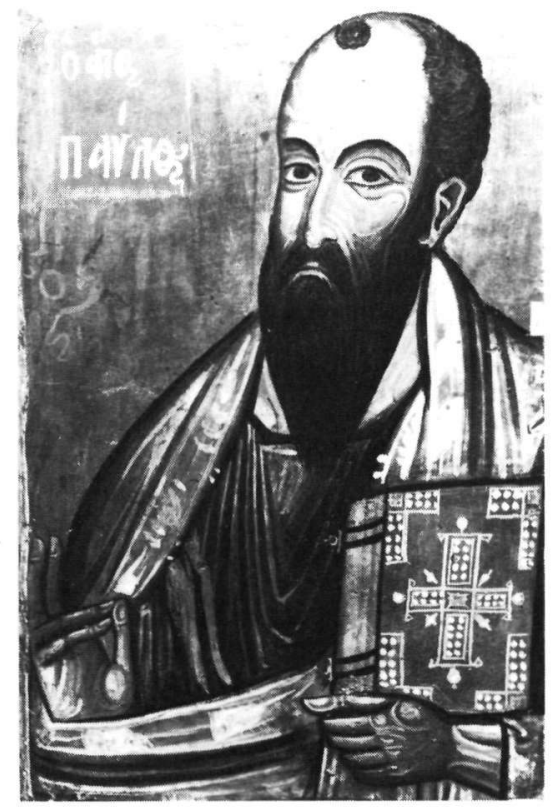

Fig. 24. Chapel of Symeon Stylites. Bust of St. Paul. 
originally must have had the size more or less equal to that of the two sets discussed above. In style St. Paul is different from that in the three other sets at Sinai ${ }^{54}$ which we believe to have been made at Sinai proper, while for the Paul icon under discussion we proposed an origin in Cyprus on the basis of a Paul icon in Nicosia ${ }^{55}$. The facial features of both Paul and John the Baptist are more expressive by linear designs than by painterly values. In the previous chapter we related the first two iconostasis beams with a Cypriote workshop working at Sinai and this raises the question whether the two icons of John the Baptist and St. Paul could likewise be products of the same Cypriote workshop working at Sinai. On second thought we now believe that the Paul icon which we had dated in the early 13th century may actually be a good deal earlier and belong to a date more approximating that of the two beams. Not that the same masters were involved since in general it seems not very likely that the monumental portraits were commissioned to the same icon painter who produced the beams with the narrative scenes in the small figure scale. Yet, as we said at the beginning of this chapter, there must have been some relation between the beam and the intercolumnar icons commissioned at the same time according to a unified program.

It has become obvious on the basis of the examples here chosen that the predominant theme of the intercolumnar icons was the Grand Deesis, sometimes in its entirety, in other cases in a reduced form. In the lastmentioned case of the John the Baptist and Paul icon we can be sure they are parts of a Grand Deesis and that the icons with Christ and the Virgin and a bust of Paul are lost or not yet traced. If such a set of Grand Deesis icons is to be related to one of the two beams by Cypriote masters it could only have belonged to the first one (Figs. 1-2) which apparently had no Deesis in the midst of the dodecaorton, whereas the other beam with the scenes of the Miracles of the Five Martyrs of Sebaste does have in its center a Deesis which, then, would not be duplicated in the intercolumnar spaces.

In view of the considerable number of beams from the early 12 th to the early 13th century one would have to assume that each was in an iconostasis which had a certain number of intercolumnar icons. We confined ourselves to the discussion of only a few of them, just sufficient to prove their existence but it would go beyond the limits of this study to go on identifying some more disiecta membra of such sets. Enough to say that there exist from about the same period more icons with busts of Christ, the Virgin and John the Baptist as intercessors, the archangels and Peter and Paul, and more research will have to be undertaken in order to demonstrate whether at least some of them can be

54. Ibid., figs. 33-38.

55. Ibid., p. 35 and fig. 40 (here further bibliography). 
grouped together in sets, fragmentary as they may be. Yet this incomplete survey has already resulted in the knowledge that the main theme of intercolumnar icons was the Grand Deesis. This, however, does not mean that it was the only subject; it is only that this subject is more clearly definable because of the serial nature of the icons. There probably were among the intercolumnar icons at Sinai some depicting either saints or narrative Gospel scenes, but here one can no longer be sure whether or not they were used to decorate an iconostasis.

Of some assistance in defining iconostasis icons is their size. Whereas the beams have an average height of $40 \mathrm{~cm}$., the majority of intercolumnar icons discussed here and others like them measures about $60 \mathrm{~cm}$. in height and this size would fit an iconostasis of a chapel rather than a larger church interior. However, there is one notable exception: a pair of Peter and Paul icons ${ }^{56}$ which, outranking all the others in size, measure $104.3 \times 89.8 \mathrm{~cm}$. This can only mean that they must have been in intercolumnar spaces of a much larger iconostasis. Presumably, though there is no way to prove it, they could have been in the main iconostasis of the basilica. No doubt there must have been an earlier iconostasis in the place now occupied by that of the Cretan painter Jeremias executed in 1612. It may not be accidental that the two above mentioned large Peter and Paul icons are kept today in the room north of the bema, i.e. in the proximity of the present iconostasis. If we are right, the present one would have been the third. In Justinian's time there must have been a marble iconostasis with curtains in the intercolumnar spaces and this iconostasis was, as we believe, crowned by a bronze cross of that period on the crossbar of which are fittingly engraved Moses receiving the tablets and Moses before the burning bush ${ }^{57}$. But when in the 12th and early 13th century the new type of iconostasis with the painted beams and intercolumnar icons were erected in considerable number, it is more than likely that the bema of the basilica would be included in this large enterprise.

The question then is: when was this new type of iconostasis introduced for the first time? As far as the beams are concerned there is clear evidence that they became fashionable in the 12th century, not excluding the possibility that there may have been a few earlier instances as indicated by the 10 th century beam fragment with the Washing of the Feet (p. 82). Similarly the great mass of the intercolumnar icons at Sinai belong to the same period, i.e. the 12th and early 13th century. Again the possibility must be left open that this type of icon may have been invented somewhat earlier in the 11th and perhaps even in the

56. Ibid., p. 33 and figs. 35-36.

57. K. Weitzmann and I. Ševčenko, The Moses Cross at Sinai, DOP 17 (1963), pp. $385 \mathrm{ff}$. 
10th century. But not before the 12th century are we on sure ground. Also Chatzidakis, on the basis of more widespread evidence, has come to similar conclusions that some icons of the 11th century may have been in an iconostasis ${ }^{58}$ but that we can be certain only in the 12th century. Thus the evidence provided by the Sinai material may well reflect the general trend of the day.

Looking at the Sinai material as a whole it will be noticed that large serial icons of the Grand Deesis were on this scale not continued after the 12th and 13th centuries. The enormous activities of these two centuries had to some extent reached a saturation point so that no more chapels needed apparently a new iconostasis. Not before the second half of the 15th century was a kind of revival when a great number of icons were produced at Sinai which consciously copy those from the 12th and 13th centuries, including a pair of Peter and Paul icons of almost the same dimensions as the "master set" have been destined for an iconostasis of considerable dimensions. These late icons are a vivid testimony in what high esteem the icons of the 12th and 13th centuries must have been held in the monastery. To the group of late 15th century revival icons belong two icons, one of a bust of Christ and the other of an intercessor Virgin, forming a Deesis, which are today still in an iconostasis in the Chapel of Constantine and Helen in the basilica ${ }^{60}$ which are close copies of one of the sets of the 12th-13th centuries which we discussed above (p. 89 and Figs. 20-22). This is a striking example not only how these icons were faithfully copied at such a late date but how they served the same function as the models.

\section{THE TITLE-SAINT ICONS}

At about the same time in which in many chapels and perhaps also in the bema of the basilica a new iconostasis was installed with a painted beam and a set of intercolumnar icons, a coherent group of huge icons was commissioned, six of which are still preserved and there may have been others all of which belong to the turn of the 12th-13th century. Four show figures of saints at full length and two in bust form. On all four sides they are framed by a series of scenes from the saint's life and it is largely this feature which makes them look distinct and at the same time self-contained. It can a priori be assumed that such prominent icons were made for specific locations but not a single one within this group is still in its original place. In the following lines we shall

58. Chatzidakis, Ikonostas (note 4), col. 341 ff. Chatzidakis, L'évolution, p. 184.

59. Weitzmann, St. Peter Icon, p. 40 and figs. 43-44.

60. Forsyth-Weitzmann, Church and Fortress, pl. XCIII A. 
make suggestions of what in each case the intended location might have been. As a whole they are larger than the intercolumnar icons we discussed above. Even so, merely from the point of view of size one or the other could, theoretically, have been in a large iconostasis but their above-mentioned self-containment does not speak in favor of their being part of a set of iconostasis icons.

It is hardly surprising that among the six should be an icon of the title saint of the monastery, St. Catherine (Fig. $25{ }^{61}$. Today this icon is relegated to the "Picture Gallery", but originally it must have been in the most prominent place where St. Catherine was worshipped since there is every indication that at the time it was created it was the most prominent icon of this saint. This is confirmed by the fact that when between 1250 and 1260 a Pisan artist painted a large icon of St. Catherine, the saint who at that time had already begun to be one of the most popular ones also in the Latin West, he was obviously inspired by our Sinai icon ${ }^{62}$. It is the same type of frontal standing Catherine raising one hand and holding a cross in the other, being crowned and dressed in a richly ornamented dress which, however, in the Pisan copy is somewhat changed and has lost its imperial connotation. Most decisive is the accompaniment of scenes from her life, though in the Western copy they only flank the saint on both sides and are not framing her on all sides. Whether the Pisan artist actually saw the icon at Sinai we do of course not know, but he or some Western pilgrim must have either copied or at least sketched the Sinai icon which -and this is our main point- must at that time have been in a most prominent place. This we assume was close to St. Catherine's burial place. She had no chapel of her own since the whole monastery had-sometime in the 10th or 11th centurybeen named after her, having originally been dedicated to the Virgin. Today whatever is left of her relics in the monastery -her head and the left hand- are deposited in the bema in a marble shrine under a marble baldachin, a structure from the year $1715^{63}$.

About that time an icon of St. Catherine, a Cretan work of the early 17th century, was set behind the tomb in a marble frame against the pilaster at the right of the apse (Fig. 26) ${ }^{64}$. This icon obviously is based on the earlier one which it copies in all essential features. The saint is depicted in the same pose, holds a cross in her right hand, and shows the open palm of her left, and wears a crown and imperial garment, only that the thorakion, perhaps no longer

61. It measures $75.2 \times 51.1 \mathrm{~cm}$. Sotiriou, Icônes, I, fig. 166; II, pp. 147 ff. Weitzmann, Crusader Icons, p. 154 and fig. 13.

62. Ibid., p. 154 and fig. 14 (here further bibliography).

63. Forsyth-Weitzmann, Church and Fortress, pls. LXXXIV-LXXXV.

64. Unpublished. 


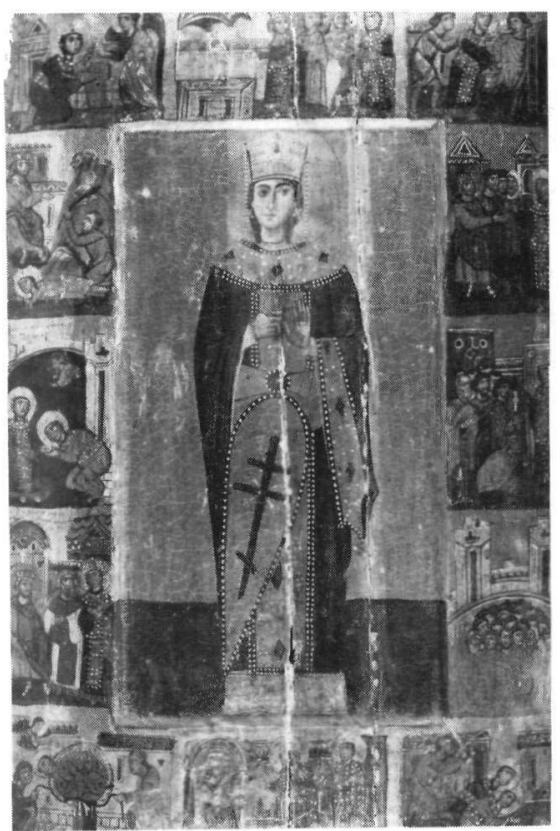

Fig. 25. Gallery. St. Catherine.

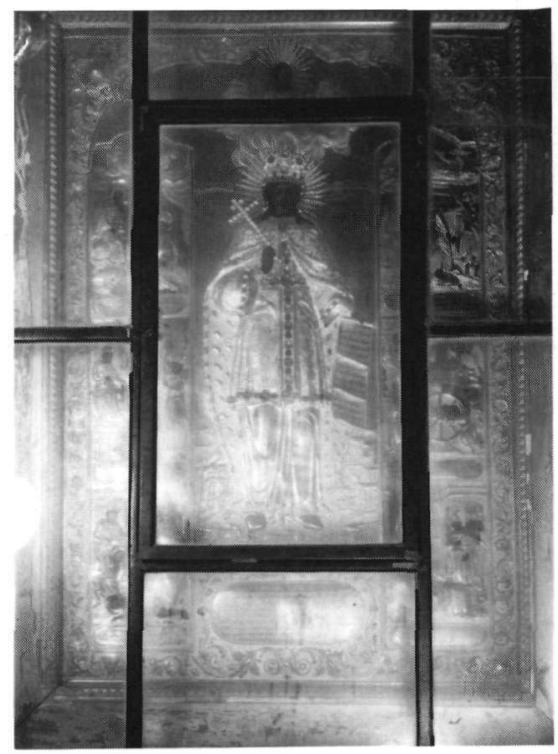

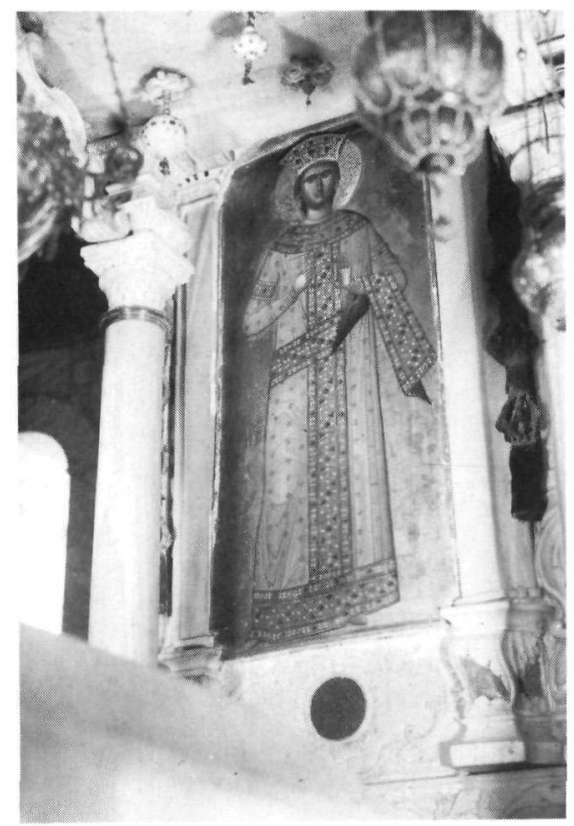

Fig. 26. Basilica, Bema. St. Catherine.

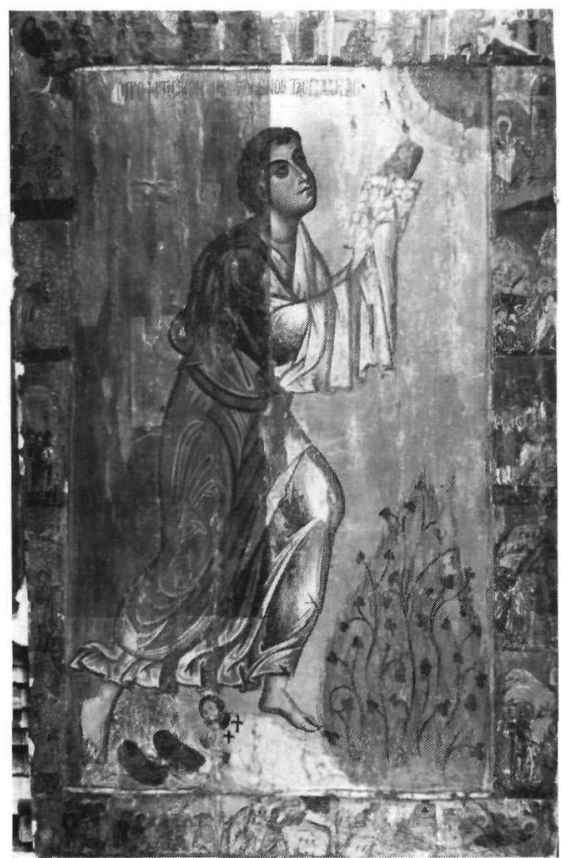

Fig. 27. Basilica, South aisle. St. Catherine. Fig. 28. New Library. Moses Receiving the Law. 
understood because it was out of fashion, is replaced by a kind of loros. Actually being of larger size ${ }^{65}$ and with no scenes from her life all around, the figure is almost twice as tall as that of the model. The implication is that this Cretan icon is a replacement of the earlier one which we assumed was at the place which held the relics. The earlier icon, too, could have been set against the marble pillar right of the apse, though perhaps not as high so that the worshipper could stand in front of it and have a closer look at the scenes from the saint's life.

But the original icon was at the time of the replacement apparently not discarded altogether but kept in a close proximity of the saint's tomb. There is today to the right of the pilaster and above the door which leads from the south aisle into the Chapel of the Forty Martyrs yet another icon of St. Catherine (Fig. 27) ${ }^{66}$ which is at least as large as the first one. Once more St. Catherine is rendered standing frontally and holding a cross, but in the left she holds a scroll instead of raising the hand. What in particular relates this icon to the first one is the cycle of scenes from the saint's life which surrounds the figure. So we assume that this icon apparently replaces the first one which was only then finally discarded and relegated to a magazine and ultimately to the "Picture Gallery". This happened only in the 19th century, the date of the third Catherine icon which is a Russian work of that period. Its painted surface is under a massive golden riza which leaves only the heads and the hands visible. Obviously it was the ostentatiousness of the glittering gold that induced the monks to remove the venerable original St. Catherine icon from the neighborhood of her tomb.

The locus sanctus which in importance even outranks St. Catherine's tomb is the Chapel of the Burning Bush behind the apse of the basilica. No wonder, then, that the largest icon within our group, and for that matter one of the largest in the whole Sinai collection depicts Moses before the burning bush, combined with his receiving the law (Fig. 28) ${ }^{67}$. This icon we believe to have been made for this chapel since among the many icons with this subject at Sinai this one is by far the most prominent. Moses, youthful as is typical since the

65. It measures $104.3 \times 46.7 \mathrm{~cm}$. The icon has been removed and the heavy marble frame dismantled after I discovered in 1960 that underneath was an encaustic panel of the 7th century representing Jephthah sacrificing his daughter. K. Weitzmann, The Jephthah Panel in the Bema of the Church of St. Catherine's Monastery on Mount Sinai, DOP 18 (1964), pp. $341 \mathrm{ff}$. Weitzmann, Sinai Icons, I, pp. 54 ff. no. B30 and pls. LXXIX-LXXXI.

66. Unpublished.

67. K. Weitzmann, The Study of Byzantine Book Illumination, Past, Present, and Future, K. Weitzmann et al., The Place of Book Illumination in Byzantine Art, Princeton 1975, pp. $24 \mathrm{f}$. and figs. $20-21$. 
Middle Byzantine period, receives with veiled hands the tablets out of the hand of God and in front of him the burning bush is prominently displayed. Under his left foot and in front of his discarded sandals there is a figure prostrate in proskynesis and praying whose name is mostly rubbed but from what follows his name it is clear that he represents the archbishop and abbot of

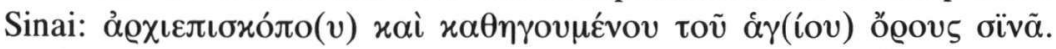

One wonders, of course, whether he is the archbishop who not only is responsible for this icon but also of some others of the set. The Moses figure is surrounded by twenty (the normal number is 16 for such icons) scenes from the life of Moses which surely are based on an illustrated manuscript and more particularly on one of the recension represented by the Octateuchs of the 12th century ${ }^{68}$.

If indeed, as we believe, this icon was made for the Chapel of the Burning Bush, where was it placed? At the present state its walls are solidly laid out with tiles in faience, a decoration from the time of archbishop Kyrillos of Crete in $1770^{69}$. In this decoration some huge Cretan icons are walled in, two of them in the north wall. One depicts a far over life size bust of the Virgin of the Hodegetria type and the other Moses before the burning bush signed by the painter Kaisarios ${ }^{70}$. This latter one very likely takes the place of our earlier locus sanctus icon. If we are correct, then the discarding of the earlier one took place only a little later than that of the Catherine icon in the bema. Both fell victim to the same era of the refurbishing of the monastery by Cretan artists in the baroque period. But differently from the icon with the frontally standing Catherine in which the Cretan copyist emulated his early model, in the case of the Moses icon the painter reinterpreted the subject of the Burning Bush in a contemporary iconography showing Moses looking at the Virgin in the burning bush hovering over a depiction of the monastery and at the top of the mountain Moses is rendered once more receiving the tablets of the law out of the hands of God surrounded by an angel glory. Our early icon may well have been in the same location, i.e., in the north wall but, if so, it was most likely not so high up in the wall but at a level more inducive to worship.

The second largest icon of the set represents St. George standing frontally, holding a spear and leaning on his shield ${ }^{71}$. Because of its size ${ }^{72}$ the artist was able to accommodate also in this case, as in the Moses icon, twenty instead of

68. Ibid., p. 28 and fig. 22.

69. M. H. L. Rabino, Le monastère de Sainte Catherine du Mont Sinai, Cairo 1938, p. 31 (inscr. 62).

70. Ibid., p. 63 (inscr. 169). Forsyth - Weitzmann, Church and Fortress, pl. C. I owe to Manolis Chatzidakis the information that Kaisarios was a monk and that there exists an icon representing St. Nicholas with his signature and the date 1708 (at the Zoodochos Pigi Chapel).

71. Sotiriou, Icônes, I, fig. 167; II, pp. 149 ff. Weitzmann, The Icon, pl. 34 (color).

72. It measures $127 \times 78.5 \mathrm{~cm}$. 
sixteen scenes from the saint's life around the central figure. Alongside of George stands a little donor figure, the monk and priest John of the Iberians. This clearly shows that the icons of our set, though laid out in unified program, are not all donated by the same person. For only the more important Moses icon had the archbishop seemingly reserved for himself the right of donorship. There can be little doubt that the icon of St. George was made for the titular chapel of this saint, a chapel which still exists on the top of the north wall of the monastery. Part of this wall had been rebuilt by Marshal Kléber when Napoleon had sent him to Sinai to restore the monastery and this means that the St. George Chapel in the present state is not very old. Still it may stand on the place where an older St. George Chapel had been erected. We mentioned at the beginning (p. 66) that this chapel has half an iconostasis beam which surely was not made for this chapel. Presently it has on the south wall an icon of the 15th century of George on horseback killing the dragon. It is the largest icon in this chapel ${ }^{73}$ and the only one on this wall, thus clearly calling attention to its being the one of the title saint of the chapel. It seems likely that this very place was originally taken by the earlier icon with the standing George and that this was exchanged at a later time against an icon with George killing the dragon because this iconography had become the preferred and more popular one.

The fourth icon in our set depicts John the Baptist ${ }^{74}$. Like St. Catherine and St. George he stands frontally and he raises his right hand in a gesture of praying and holds cross-staff and scroll with the usual inscription, "I am the Lamb of God..." in his left hand. At his feet are at the left the axe on the tree and at the right a figure in proskynesis whom Sotiriou considers rightly or wrongly to be the painter. Sixteen scenes from his life ending with the Finding of the Head surround the figure in the usual way.

There is a major chapel, accessible from the courtyard south of the basilica, which is dedicated to John the Baptist and, in accordance with the previous instances, we believe our icon to have been the focal point in this particular chapel. Presently there are three John the Baptist icons assembled here among the numerous icons in this place, two small ones on the west and south wall both of about the 13th century, and a third, a large one, in the iconostasis, a Cretan work of the 16th-17th century. Only the latter could claim to be the authoritative icon of this chapel, being even bigger than the one under consideration $^{75}$. All three icons depict John the Baptist in profile conversing with the Lord and at his feet his head in the bowl that points to the feast of the

73. Unpublished. It measures $75 \times 47.5 \mathrm{~cm}$.

74. Sotiriou, Icônes, I, fig. 168 . It measures $70.3 \times 49 \mathrm{~cm}$.

75. Unpublished. It measures $99.5 \times 59.5 \mathrm{~cm}$. 
Finding of the Baptist's Head on February 24. This iconography, because of the inclusion of the severed head, became the accepted one and it is apparently for this reason that our earlier icon with just the standing John had become more or less obsolete and was superceded by an icon with the new iconography. We meet here the same phenomenon as in the case of the George icon where the standing type of the soldier saint was superceded by the saint killing the dragon. Yet the fact that the later icon is today in an iconostasis does not necessarily mean that the earlier one too was likewise made for an iconostasis since it is not even likely that the late Cretan icon was made for the present place which contains two Russian icons even later than the John the Baptist icon, belonging to the 18th-19th century. In our century the early icon with the standing John was taken into the "Picture Gallery" together with the St. Catherine and St. George icons and also that of St. Nicholas, the fifth in our set.

Although St. Nicholas is rendered only as a bust ${ }^{76}$, the icon is larger than that of the full length John the Baptist and thus gives an impression of even greater monumentality. Here we have the title-saint icon for a St. Nicholas Chapel. Such a chapel no longer exists, but we know that a chapel dedicated to this saint was located in the southeast corner of the monastery and fell victim to the new concrete wing. Pococke had seen it in the middle of the 18th century ${ }^{77}$ and marked its location, on his map of the monastery, underneath the Chapel of Moses and Aaron. Of this latter chapel the apse with some frescoes is still visible within the so-called "Picture Gallery". The very hieratic bust of St. Nicholas of the icon, surrounded by sixteen scenes from his life, belongs to the turn of the 12th-13th century and may actually be the earliest of the six of the set. For this very St. Nicholas Chapel the iconostasis beam we discussed above (p. 68 and Fig. 3) must have been made about the same time as the icon, but it is not likely that it was produced by the same painter. One gets the impression that in general, larger figure icons were made by a different artist than the beams with their small-scale figures. It has been noticed that even within the same icon the title figure is by another hand and one of higher quality than the narrative scenes in the frames. Today the St. Nicholas icon, just like those of St. Catherine (Fig. 25), St. George and John the Baptist is exhibited in the "Picture Gallery".

76. It measures $82 \times 56.9 \mathrm{~cm}$. Sotiriou, Icônes, I, fig. 165 and col. pl.; II, pp. $144 \mathrm{ff}$. Weitzmann, op. cit. (note 1), pp. 6 ff. and fig. 6. Weitzmann, Thirteenth Century, p. 196 and fig. 21. Weitzmann, The Icon, pl. 33 (color). K. Weitzmann et al., The Icon, p. 67 (color). N. Ševčenko, op. cit. (note 14), p. 29 no. 3 and figs. pp. 182-192. V. Lazarev, Storia della pittura bizantina, Turin 1967, p. 286 and pl. 420. W. Volbach and J. Lafontaine-Dosogne, Byzanz und der Christliche Osten, Berlin 1968, p. 180 and pl. 43b. Chatzidakis, L'évolution, p. 187 and pl. XXXIX.

77. Richard Pococke, Description of the East and Some Other Countries, London 1743. 


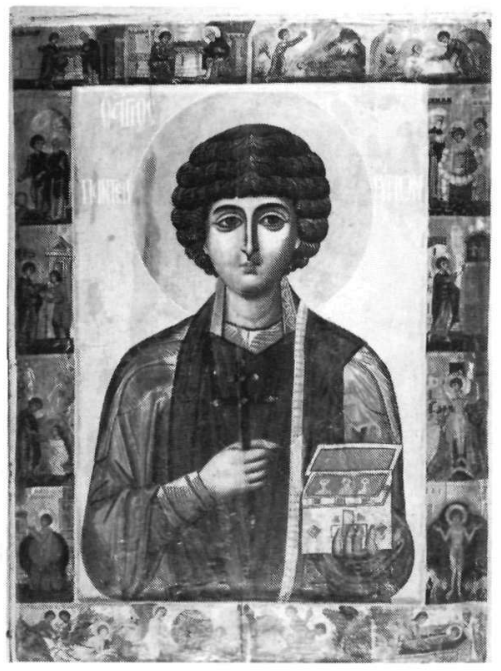

Fig. 29. Basilica, South aisle. Bust of St. Panteleimon.

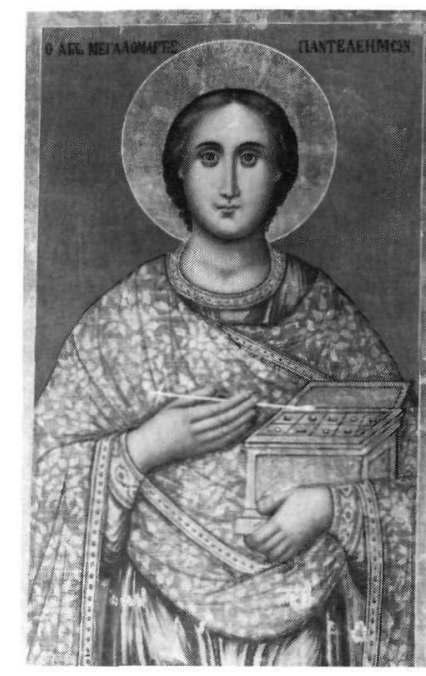

Fig. 30. Chapel of St. Panteleimon. Bust of St. Panteleimon.

The only one of the six icons with scenes from the saint's life in the frame which, though not in its original place is at least in the church, is that with the bust of St. Panteleimon (Fig. 29) ${ }^{78}$. Like all the title saints in a strong hieratic pose he holds the cross of martyrdom in his right hand and an open medicine box in his left. The light blue background with a white inscription is from about the 18th century and quite surely covers a gold ground underneath. When cleaned the inscription will most likely appear in red letters. In date it belongs to about the same period as the St. Nicholas icon, i.e. to the turn of the 12th-13th century. At the present this stately icon ${ }^{79}$ is placed high up on the wall of the south aisle over the entrance to the side chapel dedicated to the Sts. Cosmas and Damian. The monks hung it up -apparently in fairly recent timeson this spot in the realization that St. Panteleimon should be close to his fellow physician saints.

But there can be little doubt that originally the icon was destined for a chapel dedicated to St. Panteleimon. Such a chapel does exist, hidden among other small chapels on the ridge of Ras Safsaf and can be reached by a path that branches off from the Elijah Chapel. Presently there are only three icons in this small chapel; one represents the Virgin of the Akathistos, the second a

78. Not in Sotiriou. K. Weitzmann, The Selection of Texts for Cyclic Illustration in Byzantine Manuscripts, Byzantine Books and Bookmen. Dumbarton Oaks Colloquium 1971, Washington 1975 , p. 85 and fig. 23. Chatzidakis informs me that the blue background has been removed and that indeed the red inscription underneath appeared.

79. It measures $101.5 \times 71.7 \mathrm{~cm}$ 
bust of Christ, and the third a bust of St. Panteleimon (Fig. 30) ${ }^{80}$. All three were made in the 19th century as a set, since they have identical style and measurements ${ }^{81}$. It is quite obvious that the St. Panteleimon icon is copied after the early one, modernized to be sure in the taste of the 19th century, but it preserves nevertheless the basic structure of the model. In similar fashion does the physician saint hold in his left hand the open box with the medicine, but the cross of martyrdom is replaced by a professional medical implement. What apparently happened is that in the 19th century when the chapel was refurbished, the venerated old Panteleimon icon was, probably for safety reasons, brought to the monastery and replaced by a modern one which, despite the complete disregard of the style of the model, nevertheless could take its place as an object of worship.

But if the small Chapel of St. Panteleimon had a specially venerated icon of the title saint, one would expect that also other and more important outlying chapels had such focal points. The two holiest places outside the walls are, of course, the Moses Chapel on Djebel Musa on the spot where Moses received the tablets, and the Elijah Chapel, two-thirds of the way up to the former where the prophet had been fed by a raven. In the basilica there are two icons, one with Moses receiving the tablets that hangs on the wall of the south aisle (Fig. 31), and the other with Elijah fed by a raven that decorates the north wall (Fig. 32) ${ }^{82}$. These two most impressive icons we claim to have been the title-saint icons of the two above-mentioned chapels. It is hardly surprising that for this task one of the greatest icon painters of that time was chosen, an artist who proudly signed both works with his name, Stephanos -one of the earliest cases of an artist's signature on icons. They are of a stately size ${ }^{83}$ and are outdone in height only by the Moses icon made as we believe for the Chapel of the Burning Bush (p. 97 and Fig. 28). Since there are no scenes from the lives of the saints around them, the actual figure size is even larger, thus giving them a monumentality which otherwise one finds only in fresco paintings or mosaics. Moses is depicted in profile, stepping slightly forward and receiving the tablets out of the hand of the Lord; in front of him is the burning bush and between the feet the discarded sandals. It is interesting to compare this icon with the one of the Chapel of the Burning Bush. The elements are the same but the accents are placed slightly differently. In the latter the burning bush is

80. Unpublished.

81. Height between $79.5 \times 79.8 \mathrm{~cm}$; width between $49.3-49.6 \mathrm{~cm}$.

82. Sotiriou, Icônes, I, figs. 75-76; II, pp. 88 ff. K. Weitzmann, The Classical in Byzantine Art as a Mode of Individual Expression, Byzantine Art - An European Art. Lectures, Athens 1966, pp. $172 \mathrm{f}$. and figs. 135-136. Weitzmann, Byzantium and the West, pp. $63 \mathrm{f}$, and figs. 25-26, 37. Weitzmann, op. cit. (note 28), pp. $269 \mathrm{ff}$. and figs. 21-23. Elijah alone is published. Lazarev, op. cit. (note 76), p. 205, fig. 332. Weitzmann, The Icon, pl. 29 (color).

83. The Moses icon measures $130 \times 70 \mathrm{~cm}$.; the Elijah icon $130 \times 67 \mathrm{~cm}$. 


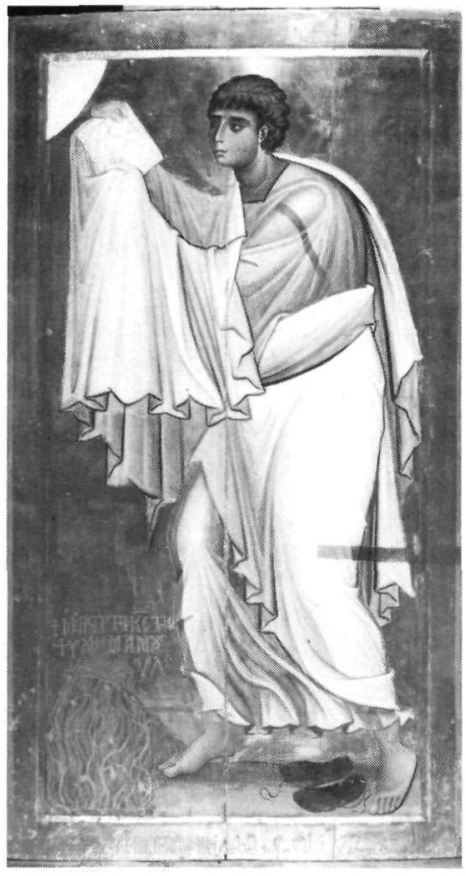

Fig. 31. Basilica, South aisle. Moses Receiving the Law.

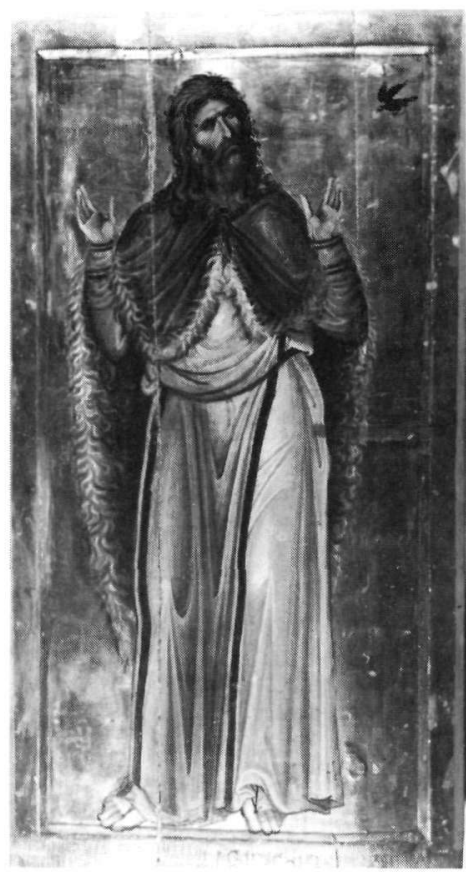

Fig. 32. Basilica, North aisle. Elijah.

appropriately much larger, thereby stressing the locus sanctus behind the basilica, whereas in the former the tablets are somewhat more emphasized.

The Chapel at the Djebel Musa, for which we assume this icon to have been made, was at an unknown time destroyed. It is shown in ruins in the lithograph of David Roberts who drew this site in 1838 and published it in his great work on the Holy Land a few years later ${ }^{84}$. But shortly thereafter the chapel was rebuilt and in the refurbished chapel there are -in addition to older icons, brought apparently from the monastery's magazine- three icons dated 1841 which were quite likely made for the occasion. What must be noticed is that the monks were apparently aware that the chapel needed a focal title-saint icon. But instead of bringing back the icon we assume to have been there originally, they replaced it by another one, which takes the prominent place on the south wall of the chapel all by itself just where one expects the title-saint

84. David Roberts, The Holy Land, Syria, Idumea, Arabia, Egypt and Nubia, I, London, 1942-43 (no plate nos.). 
icon to be. But the painter of this new icon (Fig. 33) ${ }^{85}$ made no attempt to copy the earlier one literally, but deviates from it in four respects: 1) Moses is standing motionless instead of climbing the mountain, 2) he is bearded, whereas in the Middle Byzantine period whose style is reflected in this icon, Moses is always beardless, 3 ) the object Moses receives looks more like a scroll and is held like a scroll by the hand of God (although a vertical dividing line may at the same time suggest two tablets; there is some ambiguity in the design of this object), 4) there are no discarded sandals at Moses' feet. In all four points the Moses of the icon agrees with the Moses of the Justinianic mosaic above the apse ${ }^{86}$ only that here the object in God's hand is unmistakably a scroll. So there can be no doubt that the icon painter tried to copy the mosaic in its essential iconographic features with an almost archaeological intention, but not in its style. The drapery with the crumpled folds shows all the marks of Middle Byzantine paintings. Yet there is something awkward in the design of the folds. They accumulate to high up under the armpit. Moreover the face of Moses seems too naturalistic and in disagreement with Byzantine convention. However, a final judgment whether these contradictions are the result of modern overpainting, or whether the icon is a 19th century creation, made not in an attempt to produce a forgery but a sophisticated adaptation of the Moses figure of the early mosaic, must for the time be left open until one will be able to examine the icon more closely from the technical point of view.

In analogy to this replacement one can assume that also the Elijah icon (Fig. 32) was once the focal point in the chapel dedicated to this prophet. Even more than the Moses icon it has the quality of a title-saint icon. The majestic figure in a frontal, standing pose raises both arms as if praying and he looks up to heaven from where a small raven flies down to him with a loaf of bread in its beak. This narrative element plays only a secondary role compared with the more widely spread type of Elijah icon where the prophet sits on a rock in the Sinai desert and turns around to the raven, a composition for which there exist quite a number of instances in the Sinai collection ${ }^{87}$ while the statuaric concept of our title-saint icon is, at least among the Sinai icons, unique.

In the present Elijah Chapel there is on the south wall, isolated, and in entering the chapel calling immediate attention, an icon of Elijah which takes the place which we believe the icon under discussion had once taken (Fig.

85. Unpublished. It measures $77 \times 51 \mathrm{~cm}$. Also from this icon, as Chatzidakis pointed out to me, the blue background has been removed.

86. Forsyth - Weitzmann, Church and Fortress, pls. CXXVII and CXXVIII B (color); CLXXXV-CLXXXVI B.

87. E.g. K. Weitzmann, Four Icons on Mount Sinai. New Aspects of Crusader Art, JÖB 21 (1972), pp. 286 f. and fig. 9. 
$34)^{88}$. Yet it is not a copy of its predecessor: it depicts the prophet in the form of a bust, blessing with the right hand and holding an open scroll upright in his left. The icon is a typically Cretan product from the end of the 15 th or early 16 th century. Though small compared with other title-saint icons, it can, because of its reduction to a bust form, compete with them as far as the monumental and strong hieratic expression is concerned.

One might be tempted to date the great Moses and Elijah icons into slightly different periods were it not that they are obviously created as companion pieces, both having the artist's signature in a very similar manner on the bottom frame in Greek and Arabic. The Moses has still all the characteristics of the late Comnenian style with its crumpled folds which are expressive of the agitated pose of the figure. In contrast Elijah is standing in a calm pose, the fold systems are simpler and the strong linear quality of the Moses is replaced by a more painterly quality. Just about 1200 this change of style took place and Stephanos, the painter, was capable of handling purposely two modes side by side, one traditional and the other progressive. This dates these two icons slightly earlier than those of the set of the six with scenes of saints' lives. In other words the

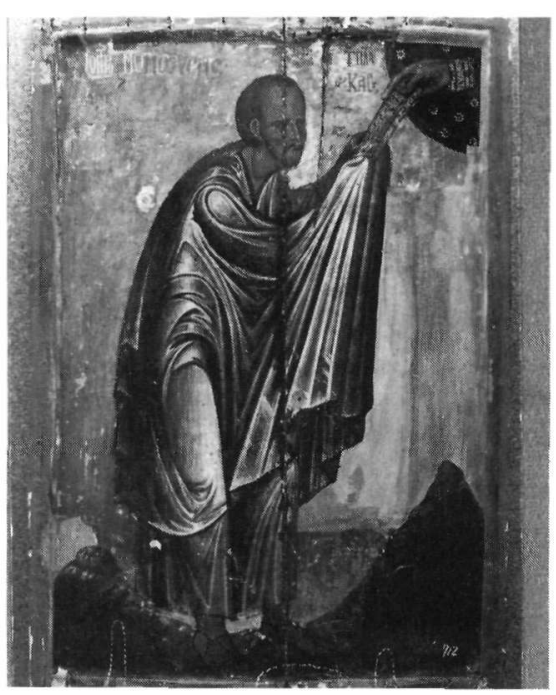

Fig. 33. Djebel Musa. Moses Chapel. Moses Receiving the Law.

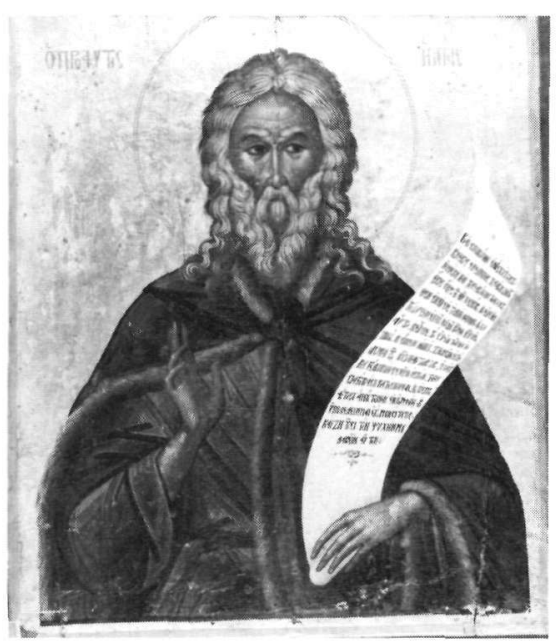

Fig. 34. Djebel Musa. Elijah Chapel. Bust of Elijah.

88. Unpublished. It measures $33.4 \times 27.2 \mathrm{~cm}$. As Chatzidakis informs me, the face, the inscription of the scroll and the background -in blue- have been overpainted by Cornaros, but recently only the blue background has been removed. 
whole idea to decorate chapels with title-saint icons may actually have started with two most important and holy places at Sinai, and by giving the commission to the best available artist.

Of all the icons we termed "title-saint icons" and have discussed so far there is not a single one in the place for which we believe it had been made with one exception. There is in the Chapel of St. Steven (Fig. 35) ${ }^{89}$ a large icon representing this saint as to be expected in a deacon's costume holding in his left hand a censer and in his veiled right hand a box with the wafer. The present metal nimbus is, of course, modern and was preceded by another one of which the nailholes are still visible. The facial features are not unlike those of St. Panteleimon (Fig. 29), although the icon is surely not by the same hand but about contemporary, i.e. the turn of the 12th-13th century. Perhaps, though it is not as sure as in the case of the Moses and Elijah icons, it may slightly antedate the set of the six.

Presently the icon is walled in into the south wall of the chapel dedicated to St. Steven, a relatively spacious chapel in which this icon, the only one on this wall, is a strong focal point. The wooden frame around the icon is of rather recent date, but in all likelihood the icon is in the very place for which it was destined. It is so located that on December 27, St. Steven's day, service could be held in front of it, thus serving its intended function.

Of course, the idea to single out an icon for special veneration is not new and harks back to the Early Christian period in which miraculous icons were exhibited in special chapels or isolated on a wall. What is new is the serial production of title-saint icons, i.e. the systematic approach to have for each important chapel within the monastery a strong focal point. At Sinai, where they are concentrated within a relatively short period, i.e. the 12th and 13th centuries, there is no indication that there was previously such a serial production. Of course individual icons must have been exhibited in important places before, like the three early 6th-7th century encaustic icons of Christ, the Virgin with soldier saints, and St. Peter ${ }^{90}$ but the point is that they are not the products of a serial commission. After the 13th century this tradition does not seem to have been continued in this expansive form, at least not at Sinai, though possibly in other places.

Of the later period there exists only one more title-saint icon at Sinai and it is interesting to see that this tradition continues more in idea than in form. In the Chapel of St. Anthony, one of the important ones within the monastery,

89. Unpublished. It measures $95 \times 63 \mathrm{~cm}$.

90. Weitzmann, Sinai Icons, I, pp. 13 ff., B.1, pls. I-II and XXXIX, XLI; pp. 18 ff., B.3, pls. IV-VI, XLIII-XLVI; pp. 23 ff., B.5, pls. VIII-X, XLVIII-LI. 


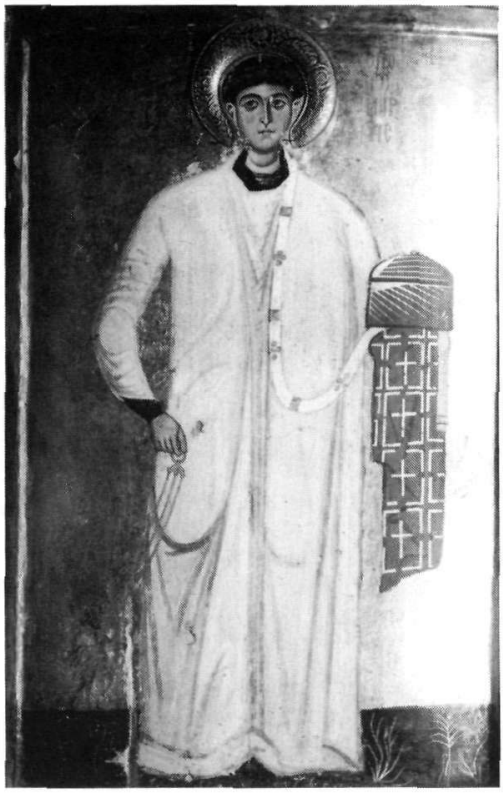

Fig. 35. Chapel of St. Steven. St. Steven.

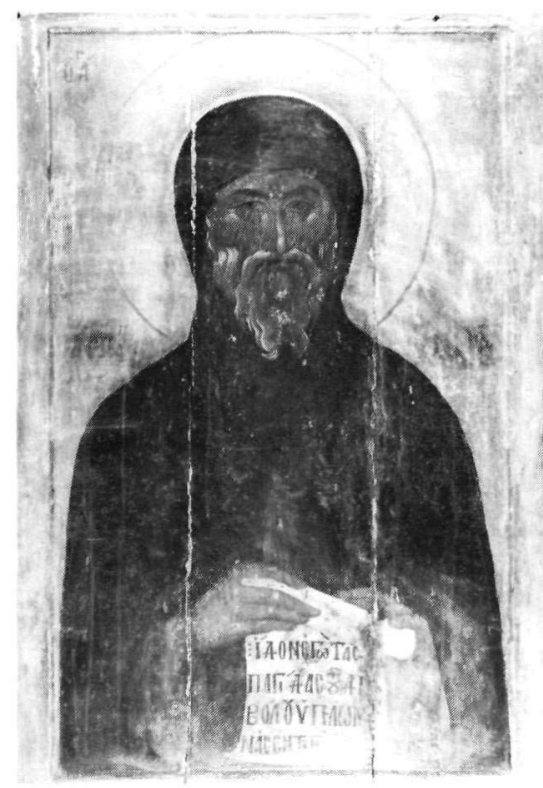

Fig. 36. Chapel of St. Anthony. Bust of St. Anthony.

accessible from the roundabout road between the entrance of the monastery and the basilica, there is a stately icon of this most important monastic saint (Fig. 36) ${ }^{91}$. When one enters this chapel one is immediately struck by the over-life size, truly monumental appearance of this somber looking whitebearded monk who holds an open scroll in both hands. What is most remarkable and at the same time quite unusual is the displaying of the icon on an easel, which is set before the north wall of the chapel. It is a Cretan work from the turn of the 15th-16th century, i.e. about contemporary with the St. Elijah icon in the Elijah Chapel (Fig. 34) which serves the same purpose as a title-saint icon. By these remarks of what precedes and follows the 12th-13th century the uniqueness of the program, worked out at Sinai for those centuries, is once more stressed.

\section{THE CALENDAR ICONS}

There is one more program to be discussed, one which is very original in its

91. Unpublished. It measures $111.5 \times 77 \mathrm{~cm}$. 
concept. There is a set of huge calendar icons (Fig. 37) ${ }^{92}$ hanging on the twelve columns which support the walls of the nave of the basilica. No parallel is known to me for such a use of calendar icons. The earliest ones we know -and they are all in the Sinai collection- date back into the 11th century, i.e. almost to the period when they were invented after Symeon Metaphrastes had at the turn of the 10th-11th century made the great compilation of saints' lives. There are four icons from the 11th century with the saints of three months on each panel which form part of an hexaptych including two more panels, one with New Testament scenes at the left, and the other with a Last Judgment to the right of the calendar icons ${ }^{93}$. In the latter standing saints are mixed with narrative scenes from the saints' lives much in the manner of miniature painting and it seems indeed quite possible that the same artists did both icons and miniatures. Moreover there is a diptych at Sinai from the end of the 11th or early 12 th century ${ }^{94}$ in which the saints are lined up singly or in groups and interrupted by only very few scenic illustrations of feast days. Both types, the hexaptych and the diptych, are meant to be used for private worship and not for the service in the church like our set of the twelve.

However, there are fragments of a third set that belongs into the 12th century and once consisted, I believe, of twelve individual plaques of which only four are preserved today, covering the months from January (Fig. 38) to April $^{95}$ i.e. the center of the ecclesiastical year that starts with September 1. These plaques were not hinged to each other to be folded but, to judge from later examples to be dealt with below, stacked up and kept in boxes. Remnants of such caskets with calendar icons have come down to us from Novgorod and Suzdal $^{96}$. Like our Sinai icons, they are bilateral with saint figures on the obverse, and christological and other feast scenes on the reverse, and they have similar dimensions; the measurements of the Novgorod plaques are $24 \times 19.5 \mathrm{~cm}$. About their usage we are well informed through the travel report of Macarius, bishop of Antioch, who visited Russia in the middle of the 17th century. This is what he has to say: "Know thou, that in this great church (the

92. Sotiriou, Icônes, I, figs. 126-130 (reproduced are those of the months of February, May and July (the latter also in color); II, pp. $117 \mathrm{ff}$. They measure between $94.7-95.7 \mathrm{~cm}$. in height and $66-67.4 \mathrm{~cm}$. in width.

93. Sotiriou, Icônes, I, figs. 136-143, 146-150; II, pp. 121 ff., 125 ff. Weitzmann, Eleventh Century, pp. $220 \mathrm{ff}$., and figs. 35-57. We itzmann, The Icon, pl. 17 (color, detail of January).

94. Sotiriou, Icônes, I, figs. 131-135; II, pp. 119 f.

95. Ibid., figs. 144-145 (month of February with backside); II, pp. 123 ff. Weitzmann, op. cit. (note 93), p. 214 and pl. 21, p. 219 and pl. 34 (month of February). Those of the months of January, March and April are still unpublished. The one of January measures $21.7 \times 13.5 \mathrm{~cm}$.

96. V. Lazarev, The Double Paged Tablets from the St. Sophia Cathedral in Novgorod, Moscow 1977. 
Dormition Cathedral in Moscow) as in the cathedrals of the Archangel and of the Annunciation as well as many other large churches and monasteries there are caskets... [which] contain twelve exquisite icons painted on thin boards. On both sides of each icon there are representations of the saints of one month... Such caskets are known as annual tablets, since they comprise the icons of saints commemorated throughout the year together with the feastdays of our Lord, the Seven Ecumenical Councils, and other holidays and saint-days, both Greek and Russian. Every church contains not one, but three or four caskets of various kinds and dimensions. They are kept on the shelves of the lecterns which stand in front of the altar and are covered with altar cloths. The Ecclesiarch places the icon of the month obverse side up on the lectern and leaves it there until the end of the month, when he replaces it with another. A candle always stands in front of it" $" 97$. While correctly connecting the Novgorod icons with this passage and considering them to be proskynetarion icons Lazarev errs only in the one point, that he considers the tablets to be a Russian invention. The parallel to the ones at Sinai is so obvious that one must conclude that such proskynetarion icons were of ultimately Greek origin, invented apparently as soon as calendar icons in general were made, and, as in the cases of so many objects and customs connected with the liturgy, later adapted by the Russians.

So coming back to our monumental calendar icons, it becomes quite clear that their manufacture was stimulated by the small proskynetarion icons. The question, however, remains whether this particular small set of which only the four above-mentioned tablets remain served as its source. Iconographically, it has many more narrative illustrations than the monumental one. This can be explained in a twofold way: either the artists of the monumental set preferred a more hieratical rendering best expressed by the frontal standing saint, or he had used another set now lost. If the situation at Sinai is comparable to that in Russia where, as Macarius tells us, a single church may have had several such sets, then it does not seem impossible that also Sinai had originally more than one.

Stylistically the set of the large icons is slightly later than the three earlier small figure sets. Whereas the latter represent the High Comnenian style, the large icons show, as is particularly clear in the scenic representations, a more painterly style. In the Baptism of Christ (e.g. Fig. 39), the craggy mountains with the fleeting highlights on their tops looking like snowcaps as well as the figures are painted in a loose brush technique. These features we have seen in the work of the "innovator" in the "three-master beam". Its Baptism (Fig. 10) shows basically the same painterly features, but the one in the calendar icon is 


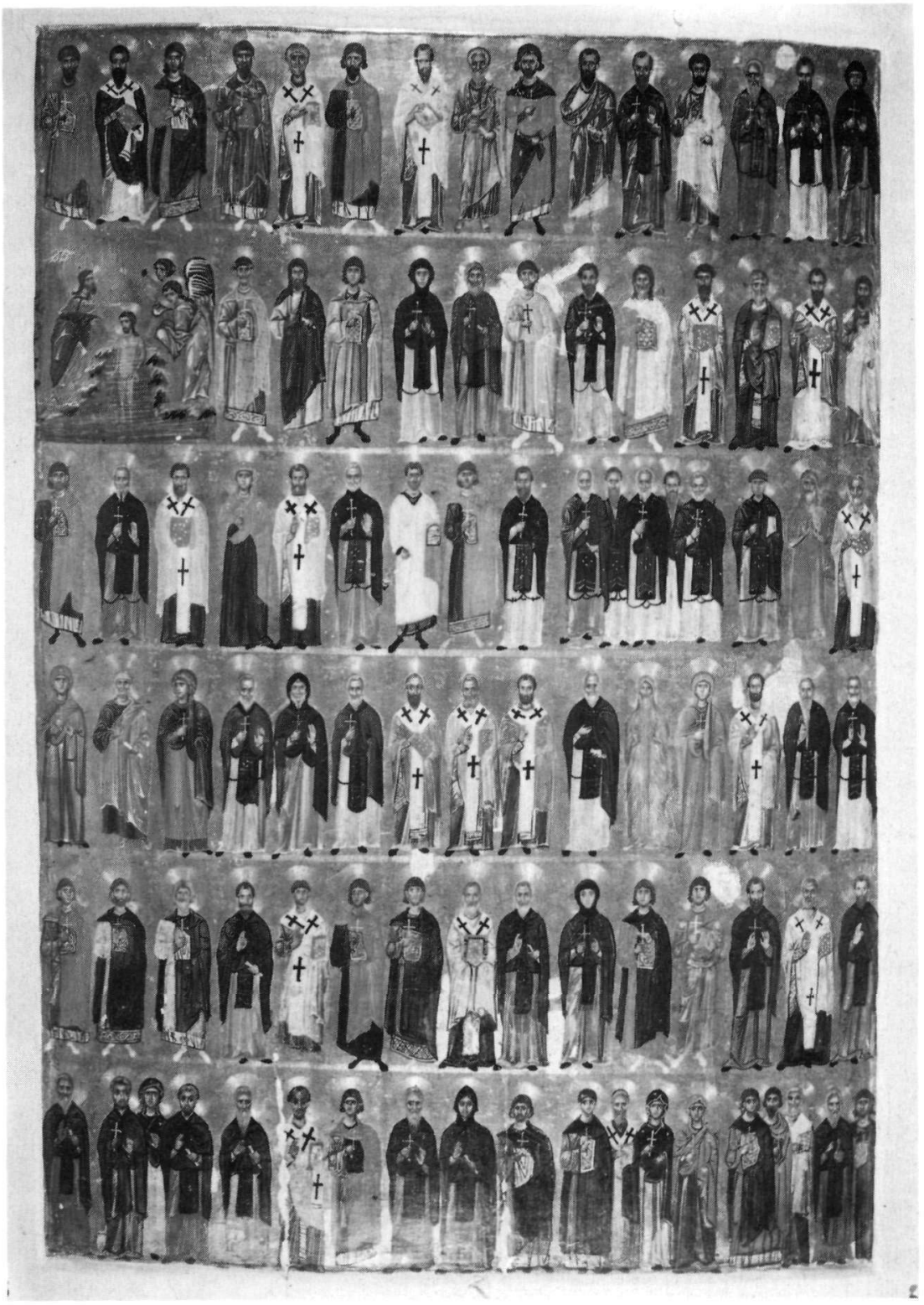

Fig. 37. Basilica. Month of January. 


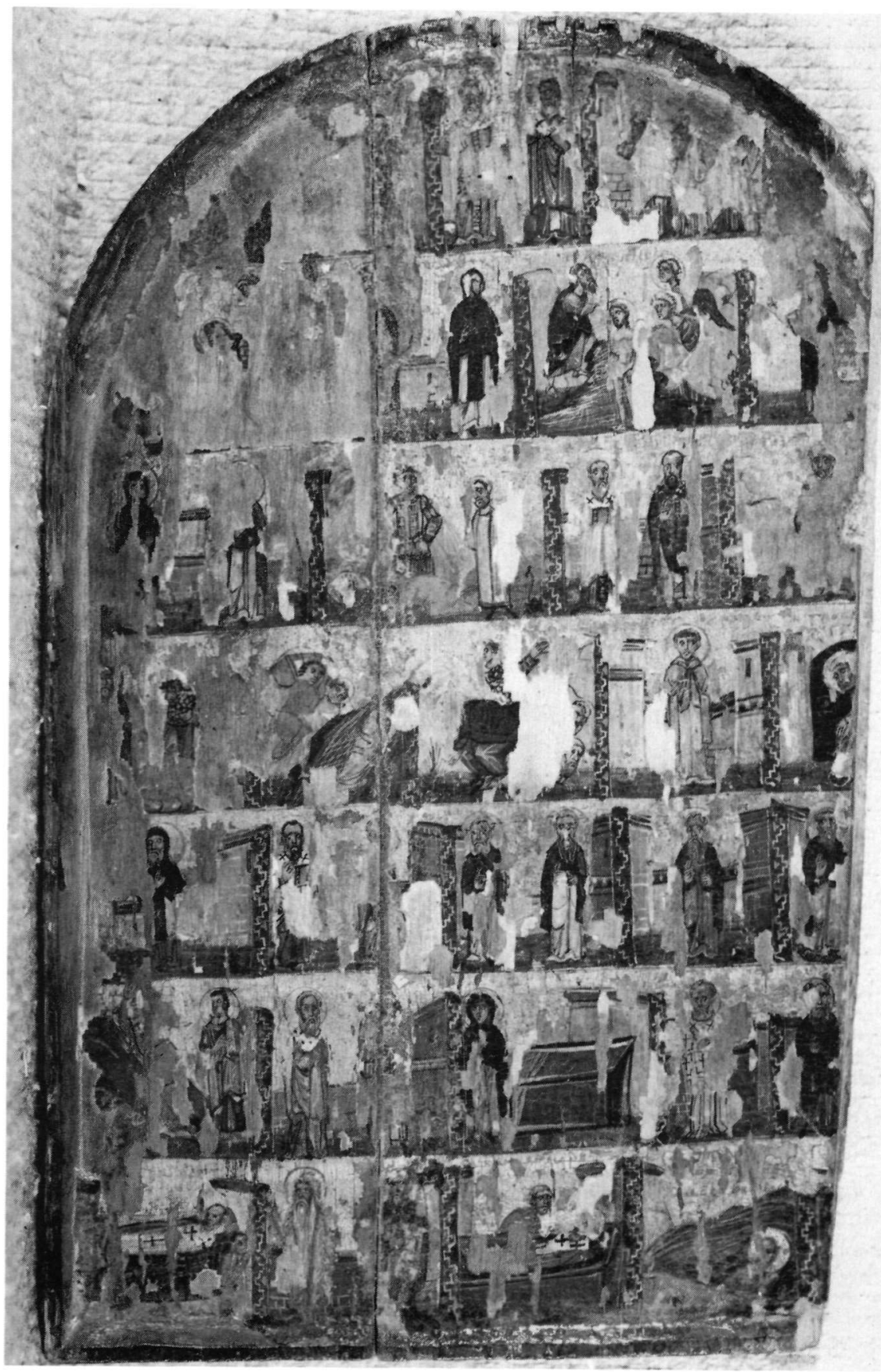

Fig. 38. Old Library. Month of January. 


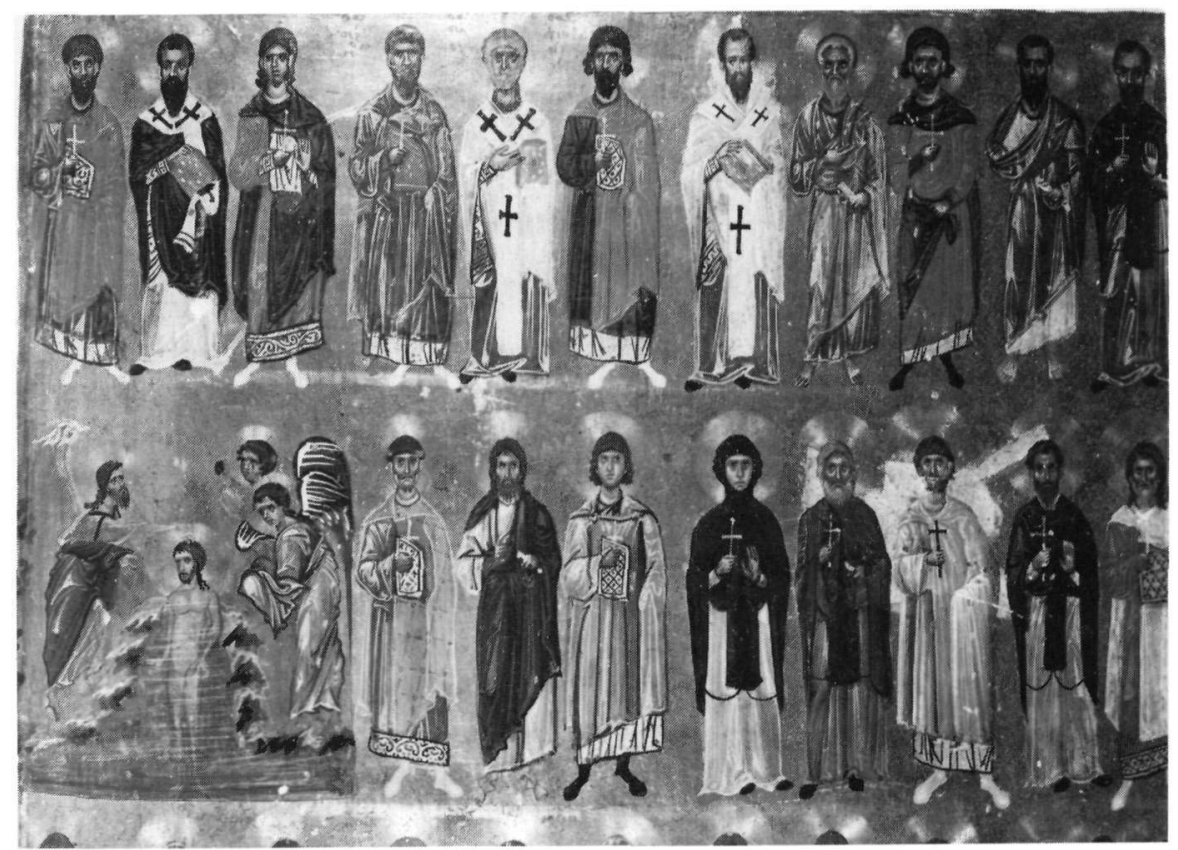

Fig. 39. Detail of Fig. 37. Baptism.

surely not by the same hand. However, we are apparently dealing with the same workshop in which the chief master of the beam had reserved for himself the central scenes, while the work on the calendar icons he left to his co-workers. Moreover, what also must have played an important role is the fact that the gigantic and at the same time somewhat monotonous task of painting rows after rows of saints led to a more speedy and less careful execution. In the "three-master beam", this new painterly manner appears side by side with the late Comnenian style and therefore is, in its beginning, contemporary with it. Consequently the style of the calendar icons cannot be much later than the end of the Comnenian style and we propose a date in the early 13 th century.

\section{CONCLUSIONS}

Two facts stand out as the result of our investigation: 1) the vastness of the projects, confined to a relatively short period, and 2) the functionalism of the programs. The focal point of the service is the iconostasis and the intention behind the programs was to decorate a considerable number of chapels within the basilica, within the precinct of the monastery and outside the walls with an iconostasis. The emphasis was twofold: 1) on the beam which in most cases was 
decorated with a cycle of the twelve feasts, the so-called dodecaorton which in many cases enclosed a Deesis in the center, and 2) on the intercolumnar icons whose main, though not exclusive, theme was once more the Deesis, most likely predominant in those cases where the beam did not include it, to avoid duplication. Both types of icons were apparently rather recent inventions and it is not even likely that they were preceded by an older type of iconostasis with a similar type of decoration. For the elaborate task, artists had to be called to the monastery from outside to establish workshops of appropriate sizes in order to cope with the new demands.

The second project was the decoration of quite likely the same chapels in and outside the monastery with what we called the "title-saint icons". This enterprise started most likely with the most important chapels, the Moses and the Elijah Chapels on Djebel Musa. The great importance which was attached to this type of icon is indicated by the fact that for the Moses and Elijah icons (Figs. 33 and 34), Stephanos, one of the greatest available icon painters of that time, was engaged. But once the idea had taken hold a large program was devised to produce serially a special type of title-saint icon in which the saint was surrounded by scenes from his life. On the respective saint's day the monks would gather in front of the icon for a special service, thus stressing its liturgical significance.

The third program was the huge calendar icons which, theoretically speaking, were not absolutely necessary for the daily service, since the small calendar icons on the proskynetarion would take care of the immediate liturgical need. Yet for reasons of an especially strong emphasis on everything connected with the liturgy, this large additional set was devised. Now on a saint's day a candle is still today lighted on a branched candlestick fastened to the column. In this way the saint's presence became visible to every worshiper in the church and did not remain confined to the celebrating priest who looked at the small icon on the proskynetarion.

A further category of icons to be used in the service are those to be displayed on the proskynetarion on the special saint's day, icons which would duplicate what is already contained in the all-inclusive calendar icons. Here no concise program, as in the other categories of icons, needed to be devised since it seems unlikely that any monastery would have an individual icon for each day of the year. Yet, how much these proskynetarion icons were considered liturgical objects at Sinai is indicated by the fact that still today they are hanging in the order of the calendar days on the north and south walls of the basilica $^{98}$. On the proper day the respective icon is taken off the hook, carried to the proskynetarion and on the next day taken back and replaced by the one next to it.

98. Forsyth-Weitzmann, Church and Fortress, pls. LVIII-LX. 
At a time when the basilica and the chapels were more or less confined to those icons which were of practical use for the services, the beholder must have been struck by the unity and clarity of these functional programs. Today one can only in one's imagination reconstruct such a state. As mentioned before, there exists not a single iconostasis from the 12th-13th century intact and of the title-saint icons only the one of St. Steven is still in its intended place. Only the set of the huge calendar icons still seems to be in its original place. It gives the impression of a festive via triumphalis when walking through the church. Now icons which used to serve as beams or as intercolumnar iconostasis icons or as title-saint icons are either hung on a wall, often high up, or placed on a ledge in the magazine in museum-like fashion. Moreover, there are many smaller single plaques, diptychs and triptychs which originally were made for private worship and which, after a monk's death, have found their way from his cell into the church. Now the clarity of the original distribution of specific types of icons has been largely obscured and church and chapels, along with the magazine and the gallery, have become museum-like deposits.

In laying out the programs as described above, one point needs to be commented on. It will be noticed that, contrary to the normal Byzantine church of the 12th and 13th century, no use has been made of fresco painting or mosaic. Mosaic decoration was, after the Justinian period in which the main apse was decorated with the Metamorphosis, only once more employed, namely, in the Chapel of the Burning Bush at an uncertain time with a mere ornamental mosaic depicting a cross $^{99}$. Frescoes were apparently not made before the second half of the 15th century when the apse of the Chapel of James Major in the basilica was decorated and a few smaller places within the monastery ${ }^{100}$, and again in 1573 when a Cretan painter decorated the apse of the trapeza with a Last Judgment ${ }^{101}$. It is hard to believe that fresco painters were not available at a time when many churches in the whole Orthodox world, including Palestine, were decorated with monumental paintings. How should one explain their absence at Sinai? Perhaps the reason was the concentration on the liturgical function of holy images which could be served better by an icon, because here the contact between the image and its worshiper was much closer physically and spiritually.

All the commissions here discussed were executed by Greek artists with the exception of the two late-13th century beams which must be credited to Crusader artists. It seems to me important to stress this point because lately so

99. Ibid., pl. C.

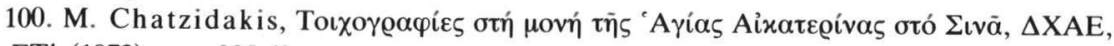
$\Delta^{\prime}, \Sigma T^{\prime}$ (1972), pp. $205 \mathrm{ff}$.

101. Huber, Heilige Berge, figs. 188-189. J. Galey, Sinai und das Katharinenkloster, Stuttgart 1979, fig. 168. 
much has been written about Crusader art at Sinai, largely by myself that one may have gotten the impression that Sinai in the 12th and 13th century was dominated by Crusader art. This concept, however, does not correspond to the reality. The execution of so many beams, intercolumnar icons, set of title-saint icons and the huge calendar icons could not have been done by calling artists individually, but required the establishment of larger workshops in which a head master had collaborators. They were all Greeks with the one exception of the two beams mentioned above. The so-called "three-master beam" is a striking witness of such collaboration and the execution of the narrative scenes around the central title saint, which were done by a lesser artist, are all signs of cooperative efforts. Yet there never developed an indigenous, Sinaitic style. Masters were called from outside, be it Cyprus or Constantinople or elsewhere, worked at Sinai for some time, and were then replaced by the next team. So if for the later 13 th century we have been able to establish a Venetian workshop, it must be seen in the light of many workshops at Sinai, those organized by Crusader artists being rather an exception than the rule.

Yet it must be realized that the great activity of Greek workshops unfolded at a time when Sinai was part of the Crusader kingdom and when the abbot of Sinai was under the jurisdiction of the Latin suffragan bishop of Petra. In the Crusader period Sinai had become for the Latin pilgrim a goal second only to Jerusalem proper and the cult of St. Catherine had spread to the West on an ever increasing scale. After all most of the saint's relics are today in the cathedral of Rouen, while Sinai itself kept only the skull and the left hand. Surely a high price was paid for such relics and the great wealth which permitted the monastery to embark on vast programs of icon painting must largely have come from the donations of pilgrims of the Western world. There must have been a close contact between the Greek and the Latin artists but iconographically and stylistically the influence of the West on Byzantine art was limited and can perhaps be detected in minor details in some scenes of the beam of the Lower Panagia Chapel (p. 71 and Fig. 6). The Greek artists, even in the Latin surrounding, kept pretty much to themselves. On the other hand the Crusader artists copied with often great empathy Byzantine style and iconography, but they carefully drew the line when Byzantine iconography was in conflict with their religious concepts as, e.g., in the scene of the Pentecost where the problem of Peter's primacy was involved (cf. p. 82).

In some respects Sinai seems to have been unique. It is hardly fortuitous that the emphasis on the title-saint icons and their serial production coincides with the development in Western art, where at that time a multiplication of altar panels takes place in order to decorate the many chapels and altars. The difference is that in a Western church the picture of the title saint is upon the altar, while at Sinai it is set against a wall, but their function is more or less the same. Another difference is that in a Western cathedral the many altars are 
under one roof and at Sinai the corresponding icons are distributed over many chapels. Whether we deal here with an independent parallel development or whether a mutual influence is involved must remain at this time an open question. One point seems nevertheless quite clear: Sinai is not a normal Greek monastery but a crossing point of many cultural influences and a place which belonged to Christianity at large.

Princeton

KURT WEITZMANN

ABBREVIATIONS

Chatzidakis, L'évolution $=M$. Chatzidakis, L'évolution de l'icone aux 11e-13e siècles et la transformation du templon. XV Congrès International d'Études Byzantines. Rapports et Co-Rapports III, Art et Archéologie, Athens 1976.

Forsyth - Weitzmann, Church and Fortress = G. Forsyth - K. Weitzmann, The Monastery of St. Catherine on Mount Sinai, The Church and Fortress of Justinian. Plates, Ann Arbor (n.d. = 1973).

Huber, Heilige Berge $=$ P. Huber, Heilige Berge. Sinai - Athos - Golgota, Ikonen - Fresken Miniaturen, Zürich 1980.

Sotiriou, Icônes = G. and M. Sotiriou, Icônes du Mont Sinai, I, Plates, Athens 1956; II, Text, Athens 1958 .

Weitzmann, Thirteenth Century $=$ Thirteenth Century Crusader Icons on Mount Sinai, Art Bull. 45 (1963), pp. $181 \mathrm{ff}$.

Weitzmann et al., Frühe Ikonen = Kurt Weitzmann, Manolis Chatzidakis, Krsto Miatev, Svetozar Radojčić, Frühe Ikonen - Sinai, Griechenland, Bulgarien, Jugoslawien, Munich 1965.

Weitzmann, Crusader Kingdom $=\mathrm{K}$. Weitzmann, Icon Painting in the Crusader Kingdom, DOP 20 (1966), pp. $51 \mathrm{ff}$.

Weitzmann, Eleventh Century $=$ K. Weitzmann, Byzantine Miniature and Icon Painting in the Eleventh Century. Proceedings of the XIIIth International Congress of Byzantine Studies, Oxford 1966, London 1967.

Weitzmann, Byzantium and the West $=\mathrm{K}$. Weitzmann, Byzantium and the West around the Year 1200. The Year 1200 - A Symposium, The Metropolitan Museum of Art, New York 1975.

Weitzmann, A Group = K. Weitzmann, A Group of Early Twelfth Century Sinai Icons Attributed to Cyprus, Studies in the Memory of David Talbot Rice, Edinburgh 1975.

Weitzmann, Sinai Icons, I = K. Weitzmann, The Monastery of Saint Catherine at Mount Sinai. The Icons, I. From the Sixth to the Tenth Century, Princeton 1976.

Weitzmann, The Icon = K. Weitzmann, The Icon. Holy Images - Sixth to Fourteenth Century, New York 1978.

Weitzmann, Ikonen = Ikonen aus dem Katharinenkloster auf dem Berge Sinai, Berlin (East) 1980.

Weitzmann et al., The Icon = Kurt Weitzmann, Gaiane Alibegašvili, Aneli Volskaja, Manolis Chatzidakis, Gordana Babič, Mihail Alpatov and Theodora Voinescu, The Icon, New York 1982.

Weitzmann, St. Peter Icon $=$ K. Weitzmann, The St. Peter Icon of Dumbarton Oaks. Dumbarton Oaks Byzantine Collection Publications, no. 6, Washington 1983.

Weitzmann, Crusader Icons $=K$. Weitzmann, Crusader Icons and Maniera Greca, Byzanz und der Westen. Studien zur Kunst des Europäischen Mittelaltes, Vienna 1984, pp. 143 ff.

All photographs in this study are reproduced through the courtesy of the Michigan - Princeton - Alexandria Expedition to Mount Sinai, with the exception of the photos on Figs. 3, 22 and 24 which were taken by Mr. Tassos Margaritof and here published with his kind permission. 